\title{
Effects of dynamic operating conditions on nitrification in biological rapid sand filters for drinking water treatment
}

Lee, Carson Odell; Boe-Hansen, Rasmus; Musovic, Sanin; Smets, Barth F.; Albrechtsen, Hans-Jørgen; Binning, Philip John

Published in:

Water Research

Link to article, DOI:

10.1016/j.watres.2014.07.001

Publication date:

2014

Document Version

Peer reviewed version

Link back to DTU Orbit

Citation (APA):

Lee, C. O., Boe-Hansen, R., Musovic, S., Smets, B. F., Albrechtsen, H-J., \& Binning, P. J. (2014). Effects of dynamic operating conditions on nitrification in biological rapid sand filters for drinking water treatment. Water Research, 64, 226-236. https://doi.org/10.1016/j.watres.2014.07.001

\section{General rights}

Copyright and moral rights for the publications made accessible in the public portal are retained by the authors and/or other copyright owners and it is a condition of accessing publications that users recognise and abide by the legal requirements associated with these rights.

- Users may download and print one copy of any publication from the public portal for the purpose of private study or research.

- You may not further distribute the material or use it for any profit-making activity or commercial gain

- You may freely distribute the URL identifying the publication in the public portal 
Post print of article published in Water Research

The publishers version is available online at: $\underline{\text { doi:10.1016/j.watres.2014.07.001 }}$

\section{Effects of dynamic operating conditions on nitrification in biological rapid sand filters for drinking water treatment}

Carson O. Lee ${ }^{*}$, Rasmus Boe-Hansen ${ }^{\mathrm{a}}$, Sanin Musovic, Barth Smets, Hans-Jørgen Albrechtsen, Philip Binning Department of Environmental Engineering, Technical University of Denmark, Miljøevej 113, 2800 Kgs. Lyngby, Denmark

${ }^{a}$ Krüger A/S, Gladsaxevej 363, 2860 Søborg, Denmark

\section{Highlights:}

- Ammonium removal was a function of total ammonium load

- Total ammonium load was more important than flow rate or ammonium concentration

- Ammonium removal capacity was 5 times larger than mean loading rate at full scale

- Ammonium removal was stratified with much of the removal at the top of the filter

- Ammonium removal and ammonia-oxidizing bacteria were closely linked

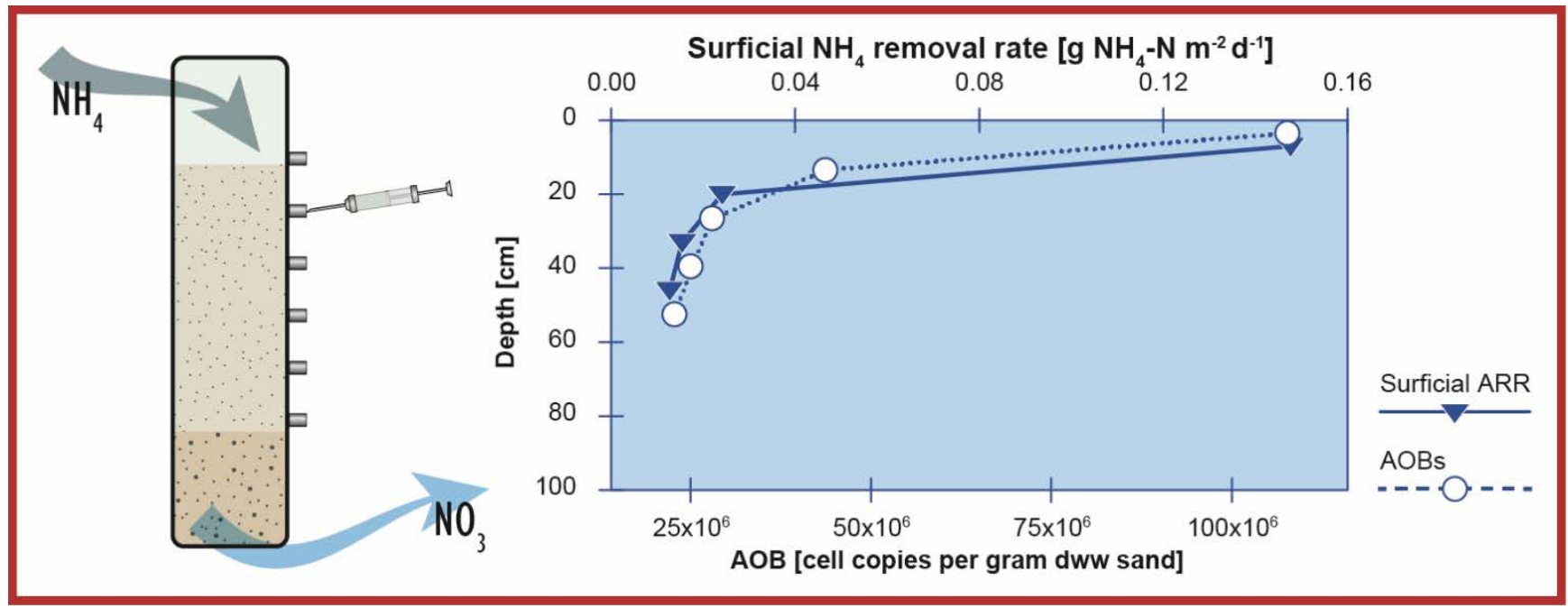




\begin{abstract}
Biological rapid sand filters are often used to remove ammonium from groundwater for drinking water supply. They often operate under dynamic substrate and hydraulic loading conditions, which can lead to increased levels of ammonium and nitrite in the effluent. To determine the maximum nitrification rates and safe operating windows of rapid sand filters, a pilot scale rapid sand filter was used to test short-term increased ammonium loads, set by varying either influent ammonium concentrations or hydraulic loading rates. Ammonium and iron (flock) removal were consistent between the pilot and the full-scale filter. Nitrification rates and ammonia-oxidizing bacteria and archaea were quantified throughout the depth of the filter. The ammonium removal capacity of the filter was determined to be $3.4 \mathrm{~g} \mathrm{NH}_{4}-\mathrm{N} \mathrm{m}^{-3} \mathrm{~h}^{-1}$, which was 5 times greater than the average ammonium loading rate under reference operating conditions. The ammonium removal rate of the filter was determined by the ammonium loading rate, but was independent of both the flow and influent ammonium concentration individually. Ammonia-oxidizing bacteria and archaea were almost equally abundant in the filter. Both ammonium removal and ammonia-oxidizing bacteria density were strongly stratified, with the highest removal and ammonia-oxidizing bacteria densities at the top of the filter. Cell specific ammonium oxidation rates were on average $0.6 \times 10^{2} \pm 0.2 \times 10^{2} \mathrm{fg} \mathrm{NH}_{4}-\mathrm{N} \mathrm{h}^{-1}$ cell ${ }^{-1}$. Our findings indicate that these rapid sand filters can safely remove both nitrite and ammonium over a larger range of loading rates than previously assumed.
\end{abstract}

Keywords: ground water; ammonium removal; loading; ammonia-oxidizing bacteria and archaea; nitrite

*Corresponding author: Tel. +45 45251693

Email address: carl@env.dtu.dk

\title{
List of abbreviations
}

A Cross section area of column $\left(\mathrm{m}^{2}\right)$

ALR Ammonium loading rate $\left(\mathrm{g} \mathrm{NH}_{4}-\mathrm{N} \mathrm{m}^{-3} \mathrm{~h}^{-1}\right)$

AOA Ammonia-oxidizing archaea

AOB Ammonia-oxidizing bacteria

ARR Ammonium removal rate $\left(\mathrm{g} \mathrm{NH}_{4}-\mathrm{N} \mathrm{m}^{-3} \mathrm{~h}^{-1}\right)$

$\mathrm{C}_{\mathrm{a}, \mathrm{in}} \quad$ Influent ammonium concentration $\left(\mathrm{mg} \mathrm{L}^{-1}\right)$

$\mathrm{C}_{\mathrm{a}, \text { out }} \quad$ Effluent ammonium concentration $\left(\mathrm{mg} \mathrm{L}^{-1}\right)$

$c_{n, i n}$ Influent nitrite concentration

$c_{n, \text { out }} \quad$ Effluent nitrite concentration

DWW Drained wet weight

NOB Nitrite oxidizing bacteria

NRR Nitrite removal rate 
NVOC Non-volatile organic carbon

z filter depth $(\mathrm{m})$

\section{Introduction}

Biological rapid sand filters are a common treatment process for drinking water production, which combines rapid sand filtration for particle removal with biological processes. They are commonly used to remove biodegradable organic matter (BOM) and ammonium from drinking water (Rittmann et al., 2012). For example, in Denmark drinking water is produced solely from groundwater that is mostly anaerobic, and almost exclusively treated by aeration followed by biological rapid sand filtration. Ammonium can cause nitrification in the distribution system, which can lead to many problems including corrosion, aesthetic problems (taste and odor), decreases in $\mathrm{pH}$, and biological instability (Rittmann et al., 2012). Incomplete nitrification can lead to nitrite accumulation (Wilczak et al., 1996), which is a toxic intermediate of the nitrification process.

Ammonium can also negatively affect free chlorine or chloramine residuals, which can lead to insufficient microbial disinfection in distribution systems (Lytle et al., 2013). In regions or countries like Denmark, that do not use disinfectants in the treatment process or in the distribution system, ammonium removal becomes important at the works to prevent microbial after growth in the distribution network. The guideline values for ammonium and nitrite in the effluent of the waterworks in Denmark are $0.05 \mathrm{mg} \mathrm{NH}_{4} \mathrm{~L}^{-1}\left(0.04 \mathrm{mg} \mathrm{NH}_{4}-\mathrm{N} \mathrm{L}^{-1}\right)$ and $0.01 \mathrm{mg} \mathrm{NO}_{2} \mathrm{~L}^{-1}\left(0.003 \mathrm{mg} \mathrm{NO}_{2}-\mathrm{N} \mathrm{L}^{-1}\right.$ ) (Miljøministeriet, 2014), which are significantly lower than the $\mathrm{EU}$ drinking water directive of $0.5 \mathrm{mg} \mathrm{L}^{-1}$ for $\mathrm{NH}_{4}$ and $\mathrm{NO}_{2}$.

Nitrification is a two-step biological process conducted by autotrophic bacteria and archaea (Niu et al., 2013). First ammonia-oxidizing bacteria ( $\mathrm{AOB}$ ) or archaea ( $\mathrm{AOA}$ ) oxidize ammonium to nitrite, which is then oxidized to nitrate by nitrite oxidizing bacteria (NOB). In both steps oxygen is the electron acceptor (Metcalf et al., 2004).

Although nitrification in biological filters is a commonly used treatment technology for removing ammonium from drinking water, the process can experience problems. Incomplete ammonium or nitrite removal can be caused by several factors including temperature (Aa et al., 2002; Andersson et al., 2001; Kors et al., 1998), insufficient oxygen (Lytle et al., 2013), phophate (nutrient) limitations (de Vet et al., 2012), and improper design and operation of filters (Lopato et al., 2013). Filters can also experience problems with nitrification due to ammonium loading rates that exceed the maximum removal rates of the filter. For groundwater, temperatures are quite stable, but filters can often operate under other dynamic conditions, and can experience sudden, large shifts in hydraulic and ammonium loading rates that could exceed the nitrification capacity of the filters, causing elevated levels of ammonium and nitrite in the effluent. Lopato et al. (2013) observed that the inlet ammonium concentration and hydraulic loading rate more than tripled in a matter of hours in biological rapid sand filters treating groundwater. These sudden changes can be caused by filter hydraulics, changes to operating parameters in upstream processes, shifts in abstraction wells, and consumer demand.

Several methodological approaches have been applied to study nitrification in drinking water filters. Tatari et al. (2013) used lab scale column assays, without backwashing, to determine nitrification biokinetics. Others have studied nitrification using lab scale batch experiments (de Vet et al., 2012; Kihn et al., 2000), pilot 
columns, and full scale filters (Kihn et al., 2002; Lopato et al., 2011). This study employs a pilot scale rapid sand filter designed to replicate full-scale filter performance, with the ability of obtaining depth profile information.

The aim of this research was to examine the effects of sudden increases of ammonium loading on nitrification, and to determine a safe operating window, in terms of influent ammonium concentrations and hydraulic loading rates, in which these filters could operate and still produce water that meets regulatory guidelines. The pilot rapid sand filter was set up at a local waterworks (Islevbro, Copenhagen Denmark), which supplies drinking water to the Copenhagen metropolitan area. After validation of the pilot rapid sand filter, short term ammonium upshift experiments were conducted at varying influent ammonium concentrations and hydraulic loading rates. The maximum ammonium removal rates (ARR) were determined, and quantification of $A O B$ using real-time quantitative PCR (qPCR) was used to directly quantify AOB on the filter media.

\section{Materials and methods}

\section{$2.1 \quad$ Islevbro water works and Pilot plant}

Islevbro water works treats anaerobic groundwater, with the main compounds of concern being ammonium and reduced forms of iron and manganese. The full-scale treatment train consists of aerators, followed by a contact chamber that provides an additional hour of contact time for iron oxidation. The aerated water then passes through up-flow primary filters designed to remove the majority of the iron from the water. After this the water flows through down-flow submerged biological rapid sand filters designed to remove ammonium and manganese, and which serves as a polishing filter for any residual iron. The secondary filters have an active depth of $0.7 \mathrm{~m}$ on top of $0.3 \mathrm{~m}$ of coarse grained support material, and are operated at an average hydraulic loading rate of $4.0 \mathrm{~m} \mathrm{~h}^{-1}$ (volumetric flow rate $\left(\mathrm{m}^{3} \mathrm{~h}^{-1}\right.$ ) divided by the cross sectional area of the column $\left.\left(\mathrm{m}^{2}\right)\right)$. Specific operating and design parameters for the full scale filter and pilot column are shown in Table $1 \mathrm{~A}$ in the supplementary information and in Lee et al. (2013).

The hydraulic loading rate and water quality varied in the full-scale waterworks filters. An example of the changing ammonium concentration in the inlet water of the pilot and full-scale filters is shown in Fig. 1. Ammonium varies rapidly, by almost a factor of five, and the hydraulic loading rate of the full-scale filters has been observed to double in a few hours. Average influent concentrations (with standard deviations) to the full scale after filter were $0.13 \pm 0.05 \mathrm{mg} \mathrm{NH}_{4}-\mathrm{N} \mathrm{L}^{-1}, 0.38 \pm 0.16 \mathrm{mg} \mathrm{Fe} \mathrm{L}^{-1}$, and $0.04 \pm 0.01 \mathrm{mg} \mathrm{Mn} \mathrm{L}^{-1}$, and NVOC was approximately $2.4 \mathrm{mg} \mathrm{L}^{-1}$ in the influent and effluent of the waterworks. NVOC is generally not highly removed in these filters. Other influent and effluent water parameters, for the full-scale filters and pilot column, are shown in Table 1. 


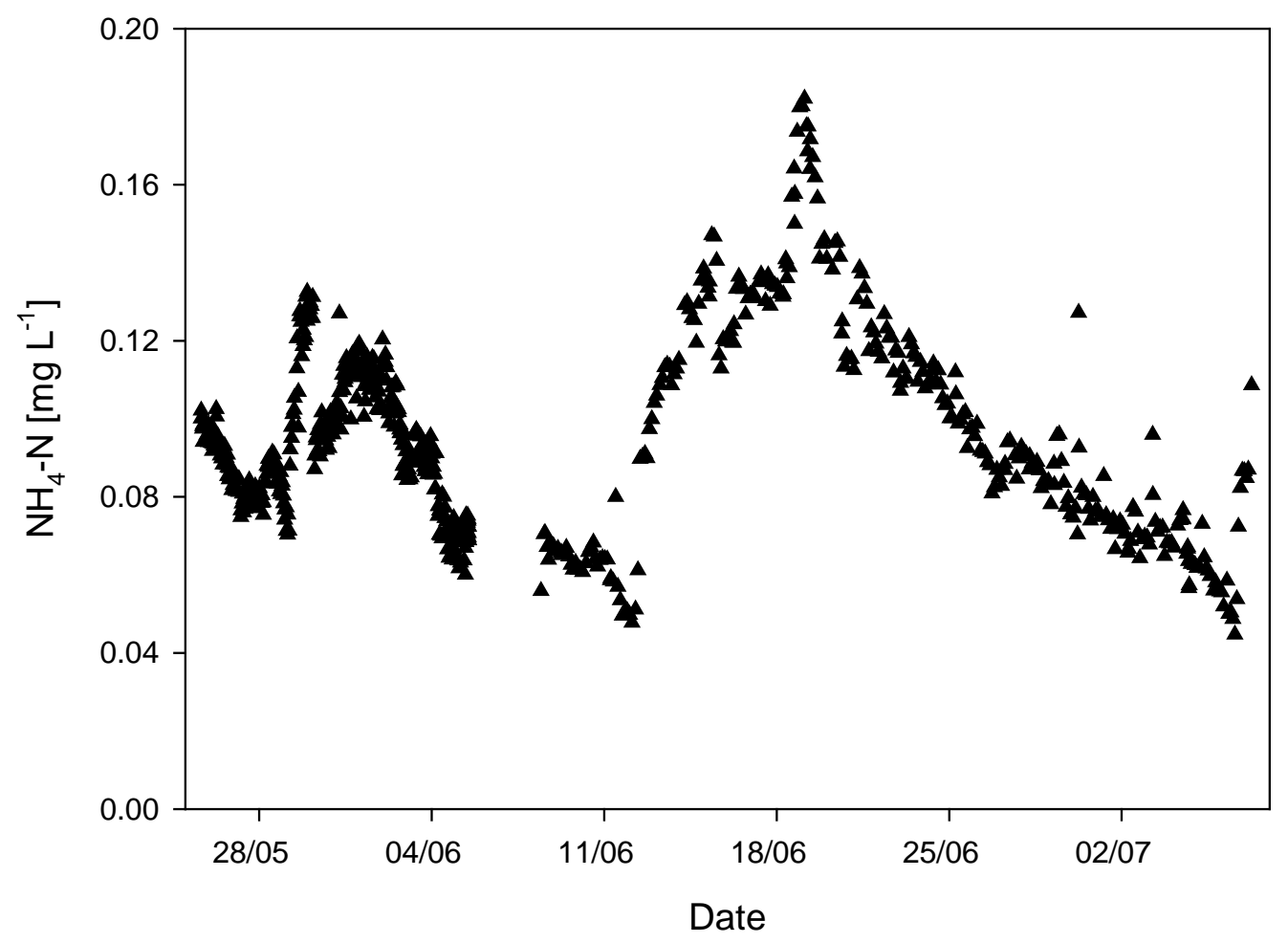

Figure 1: Inlet ammonium concentrations for the feed water supplying both the full-scale filters and pilot column at Islevbro water works in the summer of 2012. Outlet ammonium concentrations were all below the quantifiable limit of $0.02 \mathrm{mg} \mathrm{NH}_{4}-\mathrm{N} \mathrm{L}^{-1}$.

A pilot column was operated to accurately reflect the setup, operation, and performance of the full-scale secondary filters. The pilot column had a diameter of $30 \mathrm{~cm}$ with a $70 \mathrm{~cm}$ depth of filter material on top of 30 $\mathrm{cm}$ of support material, similar to the full-scale filter. Filter sand from the full-scale filter was removed in layers and transferred to the pilot column in order to ensure the entire depth profile was preserved. The filter material consisted of quartz sand with varying median grain size, density, and surface area with depth, due to the buildup of precipitates over time (Table $2 \mathrm{~A}$ ) in the Supplementary material). Sampling portals along the side of the column allowed both aqueous and sand samples to be collected. This paper refers to a reference operating condition in the pilot column, where the hydraulic loading rate was set to be $3.9 \pm 0.2 \mathrm{~m} \mathrm{~h}^{-1}$, similar to the full scale secondary filter, and where the feed water had the same ammonium concentration as the full scale secondary filter (i.e. no additional loading of ammonium, see Table 1). A submergible pump, placed in the feed channel that supplies the full-scale secondary filters, abstracted water to the pilot column identical to that supplying the full-scale filter. An initial startup time of four months was used to ensure steady state conditions in the pilot column were established, and the column was operated for 10 months prior to the start of the experiments. Filter runs during this time varied from 10-23 days, which was similar to the full-scale filter. 
Table 1: Influent and effluent water parameters for full scale filters secondary filters and pilot column.

\begin{tabular}{|c|c|c|c|c|c|}
\hline & & Influent & & & uent \\
\hline Parameter & Units & Full scale filter & Pilot column & Full scale filter & Pilot column \\
\hline NH4-N & $\mathrm{mg} \mathrm{NH}_{4}-\mathrm{N} \mathrm{L}^{-1}$ & $0.13 \pm 0.05: n=7^{a}$ & $0.1 \pm 0.024: n=749^{b}$ & $<0.01^{\mathrm{a}}$ & $<0.02^{b}$ \\
\hline $\mathrm{Fe}$ & $\mathrm{mg} \mathrm{L}^{-1}$ & $0.38 \pm 0.16: n=5$ & $0.28 \pm 0.18: n=40$ & $0.016 \pm 0.048: n=6$ & $0.009 \pm 0.007: n=19$ \\
\hline Mn & $\mathrm{mg} \mathrm{L}^{-1}$ & $0.035 \pm 0.072: n=5$ & $0.032 \pm 0.006: n=40$ & $0.001 \pm 0.0006: n=6$ & $0.001 \pm 0.0008: n=15$ \\
\hline $\mathbf{P}$ & $\mathrm{mg} \mathrm{L}^{-1}$ & $0.008 \pm 0.005: n=3$ & $0.01 \pm 0.004: n=30$ & $0.012 \pm 0.009: n=6$ & $0.01 \pm 0.004: n=8$ \\
\hline Alkalinity & meq L ${ }^{-1} \mathrm{HCO}_{3}$ & 5.5 & - & 5.4 & - \\
\hline NVOC & $\mathrm{mg} \mathrm{L}^{-1}$ & 2.4 & $2.61 \pm 0.14: n=6$ & 2.4 & $2.65 \pm 0.14: n=6$ \\
\hline pH & & 7.3 & $7.38 \pm 0.04: n=7$ & 7.3 & $7.32 \pm 0.04: n=6$ \\
\hline Temperature & ${ }^{\circ} \mathrm{C}$ & 9.1 & $9.8-10.8$ & 10.8 & $9.8-10.8$ \\
\hline DO & $\mathrm{mg} \mathrm{L}^{-1}$ & 9.3 & 9.6-10 & 8.6 & 9.4-9.7 \\
\hline
\end{tabular}

a Ammonium analyzed with colorimetric method with quantification limit of $0.01 \mathrm{mg} \mathrm{NH}_{4}-\mathrm{N} \mathrm{L}^{-1}$

b Ammonium analyzed with auto analyzer with quantification limit of $0.02 \mathrm{mg} \mathrm{NH}_{4}-\mathrm{N} \mathrm{L}^{-1}$

\pm std dev

- Not analyzed

After the startup of the filter, tracer tests were performed by spiking $50 \mathrm{~mL}$ of a $5 \% \mathrm{NaCl}$ solution into the influent for 10 seconds and measuring the change in conductivity in the effluent. The tracer tests were run 17 days after backwashing the column and showed that there was little mixing, and that there was no observed channeling or short circuiting in the column.

\subsection{Ammonium load shift experiments}

Short term ammonium load shift experiments were conducted to determine the ammonium removal capacity of the filter at either increased influent ammonium concentrations, increased hydraulic loading rates, or both. The volumetric Ammonium Loading Rate is defined as volumetric $A L R=Q \frac{C_{\text {in }}}{A \Delta z}$, where $\mathrm{Q}$ is the volumetric flow rate, $c_{a, i n}$ is the influent ammonium concentration, $A$ is the cross sectional area of the filter, and $\Delta z$ is the active depth of the filter bed $(70 \mathrm{~cm})$, and does not include the support material. The corresponding volumetric Ammonium Removal Rate is calculated using volumetric $A R R=Q \frac{C_{a, \text { in }}-C_{a, \text { out }}}{A \Delta z}$. When determining the volumetric ARR of the entire column, $c_{a, \text { out }}$ is the concentration of ammonium measured in the effluent and $\Delta z$ is the active depth of the filter bed $(70 \mathrm{~cm})$. The ammonium removal capacity of the filter is the maximum ARR of the filter. When determining the ARR at different depths of the filter, $\Delta z$ is the depth between sampling points and $c_{a, i n}-c_{a, \text { out }}$ is the change in ammonium concentration between sampling points. The maximum surficial ARR was also examined, and is determined by division of the maximum volumetric ARR at each depth, by the surface area per volume of filter sand (Table 1A in Supplementary Material). The average surficial ALR 
for the column was determined by division of the volumetric ALR of the column, by the weighted average of the surface area per volume of the filter media in the column.

The Nitrite Removal Rate for the column is defined as $N R R=Q \frac{\left(C_{a, i n}-C_{a, o u t}\right)-\left(C_{n, \text { in }}-C_{n, \text { out }}\right)}{A \Delta z}$, where $\mathrm{c}_{\mathrm{n}, \mathrm{in}}-\mathrm{c}_{\mathrm{n}, \text { out }}$ is the difference in nitrite in the influent and effluent of the column.

During the short term ammonium load shift experiments, a constant load of an ammonium stock solution was dosed to the influent flow through a port (Fig. 2) using a peristaltic pump (Ole Dich, 110 ACR) for six hours, since initial experiments showed that this was enough to ensure the column attained steady state with a constant effluent ammonium concentration. After six hours water samples were collected with depth in the column, and the ammonium load was returned to reference operating conditions. A solution of $500 \mathrm{mg} \mathrm{NH} \mathrm{N}_{4}-\mathrm{N}$ $\mathrm{L}^{-1}$ using $\mathrm{NH}_{4} \mathrm{Cl}$ (Merck chemicals) was dosed, and the ammonium load was varied for each experiment by changing the feed rate on the peristaltic pump. The experiments were conducted over two consecutive filter runs, with 23 days between backwashing, which was the longest time between backwashes observed in the full-scale filters. All experiments were operated under reference loading conditions for at least 3 days before the next load increase experiment. The periods with increased loading and time between experiments was kept short to minimalize changes in the biological make-up of the column, and to prevent any carry over effect from one experiment to another. At reference operating conditions, the volumetric ALR in the column ranged from 0.22 to $1.13 \mathrm{~g} \mathrm{NH}_{4}-\mathrm{N} \mathrm{m}^{-3} \mathrm{~h}^{-1}$ (0.04 to $0.20 \mathrm{mg} \mathrm{NH}_{4}-\mathrm{N} \mathrm{L}^{-1}$ ), with an average ALR of $0.56 \mathrm{~g} \mathrm{NH}_{4}-\mathrm{N} \mathrm{m}^{-3} \mathrm{~h}^{-1}$. The fluctuation in ALR was due to operating conditions in the primary filters. The upshifts in ALRs applied to the column ranged from 2.07 to $9.35 \mathrm{~g} \mathrm{NH}_{4}-\mathrm{N} \mathrm{m}^{-3} \mathrm{~h}^{-1}\left(0.40\right.$ to $\left.1.68 \mathrm{mg} \mathrm{NH}_{4}-\mathrm{N} \mathrm{L}^{-1}\right)$ at the reference hydraulic loading rate of $3.9 \mathrm{~m} \mathrm{~h}^{-1}$. Ammonium was also upshifted by doubling the hydraulic loading rate to $7.9 \pm 0.02 \mathrm{~m} \mathrm{~h}^{-1}$, to determine if the ammonium removal depended on flow rate, influent ammonium concentration, or if it strictly depended on total volumetric ammonium loading of the filter. For the ammonium upshift experiments at the increased hydraulic loading rate, the increased volumetric ALR varied from 2.73 to $10.25 \mathrm{~g} \mathrm{NH}_{4}-\mathrm{N} \mathrm{m}^{-3} \mathrm{~h}^{-1}(0.24$ to $0.9 \mathrm{mg} \mathrm{NH}_{4}-\mathrm{N} \mathrm{L}^{-1}$ ). The dissolved oxygen (DO) in the effluent never dropped below $7.6 \mathrm{mg} \mathrm{L}^{-1}$ in any experiments, and the $\mathrm{pH}$ ranged from 7.3 to 7.4. Alkalinity in the water was sufficiently high (5.5 meq $\mathrm{L}^{-1}$ as $\mathrm{HCO}_{3}$ ), and therefore was not a limiting factor in nitrification (Biesterfeld et al., 2003).

\subsection{Water sampling}

Water samples were collected in the influent and effluent of the pilot column every hour during the experiments to verify constant loading conditions, and confirm a steady state effluent concentration before taking depth samples. Samples were collected via the sampling ports at depths of 7, 20, 33, 46, and $59 \mathrm{~cm}$ (Fig. 2). A sterile $0.80 \times 120 \mathrm{~mm}$ needle was inserted into a sampling port for all samples except the effluent. The influent sample was taken from a sampling port $6 \mathrm{~cm}$ above the sand. Samples were collected from the bottom to the top of the column, and sampling took approximately 10 minutes total.

To collect water samples in the full-scale filter, stainless steel sampling tubes were installed in the full-scale filter, where the filter material for the pilot column was collected. The pipes were positioned $5 \mathrm{~cm}$ apart at depths of 10, 20,30, and $40 \mathrm{~cm}$. A fifth sampling tube was placed $2 \mathrm{~cm}$ above the filter sand to sample the influent. Samples were collected with a peristaltic pump (Ole Dich, $110 \mathrm{ACR}$ ) at a rate of $50 \mathrm{~mL} \mathrm{~min}^{-1}$. For ammonium, nitrite, and nitrate, the samples were immediately filtered through a sterile $0.20 \mu \mathrm{m}$ filter and stored at $4{ }^{\circ} \mathrm{C}$. All samples were analyzed within 24 hours, or frozen at $-20^{\circ} \mathrm{C}$ and analyzed within 2 weeks. 
For iron, manganese, and phosphorous, samples were not filtered and immediately acidified with $65 \%$ nitric acid to a $\mathrm{pH}$ of 2 , and stored at $4{ }^{\circ} \mathrm{C}$.

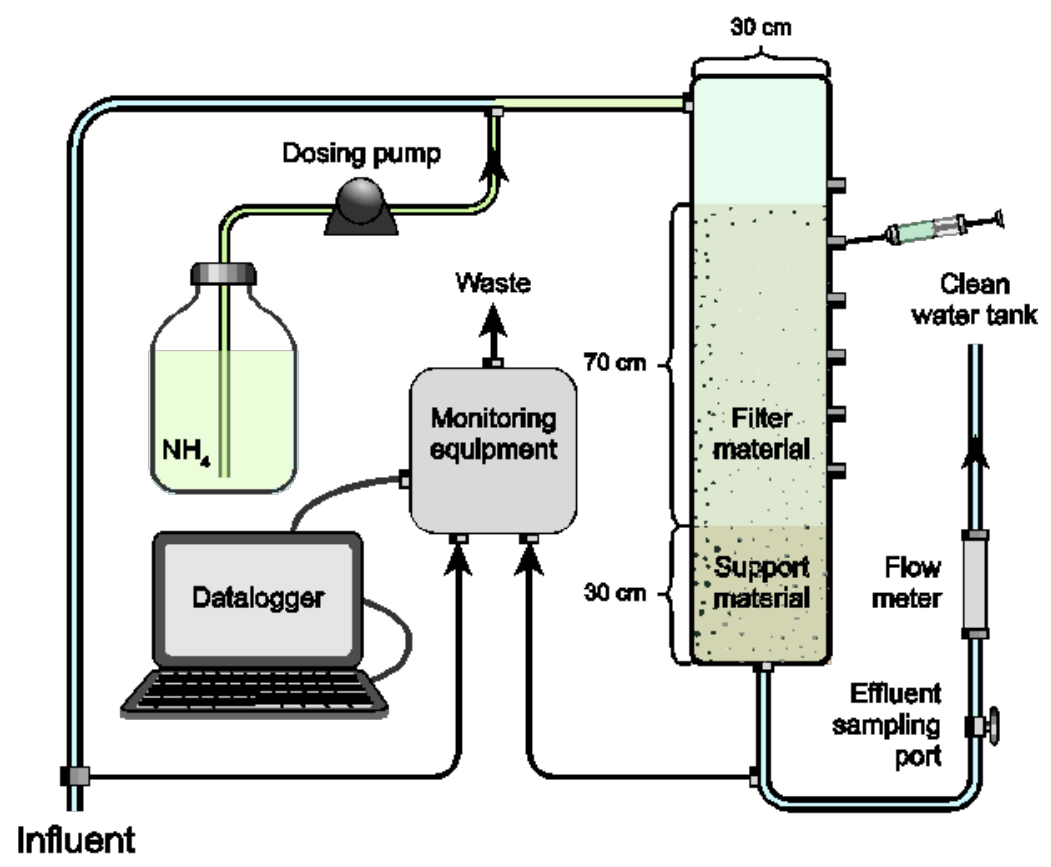

Figure 2: Schematic of pilot column at Islevbro water works.

\subsection{Analytical methods}

Ammonium in the inlet and outlet of the column was initially monitored using a $\mathrm{HACH}^{\circledR}$ Amtax sc ammonium analyzer (range of 0.02-5.0 $\mathrm{mg} \mathrm{NH}_{4}-\mathrm{N} \mathrm{L}^{-1}$ ) with a sample frequency that ranged from 10 minutes to 2 hours (Fig. 1). All other reported ammonium and nitrite values, including all values reported during the short term increased load experiments, were analyzed using colorimetric methods according to APHA 4500-NH3-F and APHA 4500-NO2-B (Clesceri et al., 1998) with quantification limits of $0.01 \mathrm{mg} \mathrm{NH}_{4}-\mathrm{N} \mathrm{L}^{-1}$ and $0.002 \mathrm{mg} \mathrm{NO}_{2}-\mathrm{N} \mathrm{L}^{-1}$. Nitrate was determined using a colorimetric method with a Bran Luebbe ${ }^{\circledR}$, Auto Analyzer 3 digital colorimeter. The $\mathrm{pH}$ was determined onsite using a hand held $\mathrm{pH}$ meter $\left(\mathrm{HACH}^{\circledR}, \mathrm{HQ} 40 \mathrm{~d}\right)$. Online measurements of dissolved oxygen (DO) and temperature ( $\mathrm{HACH}^{\circledR} \mathrm{LDO}$ sensor), electrical conductivity $\left(\mathrm{HACH}^{\circledR}, 3700 \mathrm{sc}\right)$, and turbidity $\left(\mathrm{HACH}^{\circledast}\right.$, Ultraturb plus $\mathrm{sc}$ ) were monitored online, in the inlet and outlet of the pilot column. All phosphate, iron, and manganese results were determined using ICP-OES (Varian; Vista-MPX CCD Simultaneous ICP-OES), and was analogous to EPA method 6010C (USEPA, 2007) .

\subsection{Quantification of $A O B, A O A$, and total bacteria by $q P C R$}

Grab samples of the filter material were collected in the pilot column at the sample portal depths. Samples were collected before backwashing the column (right before the upshift experiments started) and before backwash after the first filter run during the increased loading experiments. Four depth samples were collected during each sampling event leading to total of 8 samples. Approximately $5 \mathrm{~mL}$ of sand was taken per sample, for a total sample volume of $40 \mathrm{~mL}$, which comprised approximately $0.1 \%$ of the active filter volume. 
To sample the sand the sampling ports were first removed, and a sterile, $135 \mathrm{~mm}$ long sampling tube was used to collect the filter material. The sample was then immediately put on ice and, either transported directly back to the lab, or stored in a freezer until transported to the lab, where they were stored at $-20^{\circ} \mathrm{C}$ until DNA extraction. For each grab sample, DNA was extracted from $0.5 \mathrm{mg}$ drained wet weight (DWW) filter material using a MP FastDNA ${ }^{\mathrm{TM}}$ SPIN Kit (MP Biomedicals LLC., Solon, USA), per manufacturer's directions, and stored in $100 \mu \mathrm{L}$ Tris-EDTA buffer at $-20^{\circ} \mathrm{C}$. DNA concentration and purity was analyzed by spectrophotometry (NanoDrop Products, Wilmington).

Total Eubacteria, Ammonia Oxidizing Bacteria (AOB), and Ammonia Oxidizing Archaea (AOA) was quantified by real-time quantitative PCR (qPCR) analysis. The specific regions on $16 \mathrm{~S}$ ribosomal-RNA gene were targeted with the following primer sets: $1055 \mathrm{f}$ and $1392 \mathrm{R}$ for total Eubacteria (Ferris et al., 1996; Lane, 1991) and CTO189A/B/C and RT1 for AOB quantification (Hermansson and Lindgren, 2001). Furthermore, specific regions of a functional amoA gene, encoding a subunit-A of the ammonia monooxygenase, were targeted for quantification of Ammonium Oxidizing Archaea (AOA) and AOB , using amoAF and amoAR (Francis et al., 2005) and amo1F and amo2R (Rotthauwe et al., 1997) primer sets, respectively. The qPCR were run in triplicate on a Chromo4 thermocycler using Opticon Monitor 3 software (Bio-Rad).

Each qPCR reaction contained $12.5 \mu \mathrm{l}$ of $2 \times$ iQ SYBR Green Supermix (catalog no. 170-8880, Bio-Rad Laboratories), $500 \mathrm{nM}$ of each primer, DNA template (10 ng), and DNA/RNA-free water to $25 \mu \mathrm{l}$. The thermal cycling conditions consisted of an initial 5 minutes denaturation at $95^{\circ} \mathrm{C}$ followed by 40 cycles of 30 seconds at $94{ }^{\circ} \mathrm{C}$; primer annealing of 30 seconds at $55^{\circ} \mathrm{C}$ and $56^{\circ} \mathrm{C}$ for respectively Total Eubacteria and AOB, and 1 minute extension at $72{ }^{\circ} \mathrm{C}$. The final step in the run was a DNA extension at $72{ }^{\circ} \mathrm{C}$ for 10 minutes.

The qPCR results were quality checked by melting curve analysis after 40 th cycle (gradient $0.2^{\circ} \mathrm{C} / \mathrm{s}$, range 70 $95^{\circ} \mathrm{C}$ ) (Ririe et al., 1997). All melting curve analyses revealed a single peak, indicating specific DNA fragment amplification (data not shown). The gene-copy number was obtained by interpolating the obtained cycle threshold $(\mathrm{Ct})$ values of the sample reaction against standard curve developed with known gene copy numbers. The values were subsequently converted to the bacterial cell densities, per gram of drained wet weight ( $d w w$ ) sand, under the assumption of one 16S rRNA gene copy per bacterial cell on average (Lee et al., 2006).

\section{Results and discussion}

\subsection{Pilot column validation}

To validate that the pilot column reproduced the behavior of the full-scale filters, water samples collected over depth, in both the pilot column and the full scale filter, were compared for ammonium, iron, and manganese (Fig. 3). All samples were collected on the same day, and both the pilot column and full-scale filter were backwashed the day before sampling. The inlet concentrations varied slightly for all examined compounds because the pilot and full-scale filter samples were taken several hours apart. Even though the influent ammonium concentration varied, ammonium was removed to below detection limits in the top $20 \mathrm{~cm}$ of both the pilot column and full-scale filter. Biological ammonium removal was verified with a nitrogen balance showing that the removed ammonium was converted to nitrite or nitrate. The iron and manganese depth profiles also showed similar removal, with most of the iron and manganese being removed in the top of the filter. Given the $\mathrm{pH}, \mathrm{DO}$ (Table 1), and contact time, the iron was most likely in the form of Fe(III) precipitates (flocks) (Stumm and Lee, 1961) by the time it reached the secondary filter, and therefore removal was mainly 
due to filtration. Manganese was likely removed by a combination of biological and autocatalytic processes on the filter media (Sahabi et al., 2009). The similar removal in the pilot and full-scale filter for all three compounds verified that the pilot column accurately reproduced both the biological removal and the particle retention observed in the full-scale filter, giving confidence that the results obtained by the experiments performed in the pilot filter could be transferred to the full-scale filters.
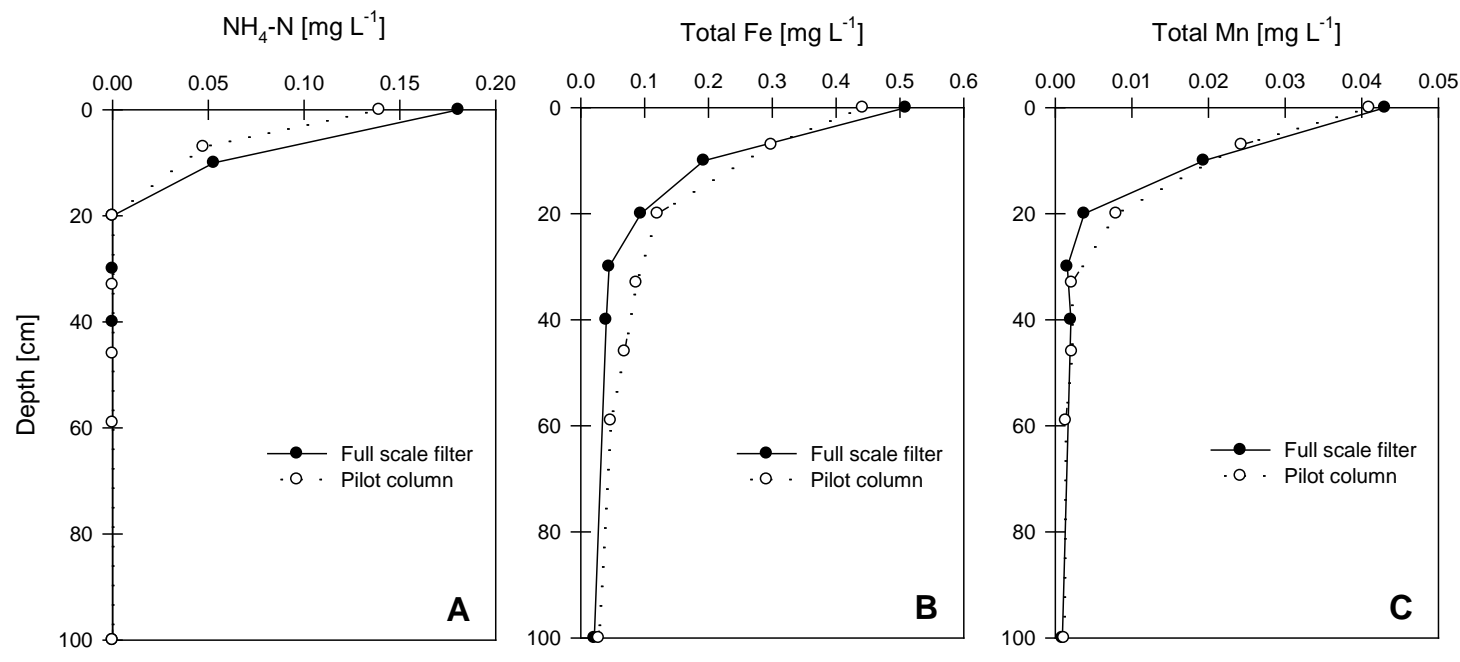

Figure 3: $\mathrm{NH}_{4}-\mathrm{N}$, total $\mathrm{Mn}$, and total Fe depth profiles for Islevbro full-scale filter and the pilot column operating under reference conditions. All samples were collected on the same day, 4 months after the startup of the pilot column.

\subsection{Relationship between $\mathrm{NH}_{4}$ load and removal}

Short term ammonium loading upshift experiments, at the reference hydraulic loading rate of $3.9 \mathrm{~m} \mathrm{~h}^{-1}$, showed that the filter could perform well under sudden shifts in ammonium concentrations, and removed ammonium to below detection limits up to a volumetric ALR of $3.1 \mathrm{~g} \mathrm{NH}_{4}-\mathrm{N} \mathrm{m}^{-3} \mathrm{~h}^{-1}$ (Fig. 4), where ammonium was detected in the effluent. Beyond this $A L R$, the filter quickly reached its maximum ARR $\left(A R R_{\max }\right)$ of approximately $3.4 \mathrm{~g} \mathrm{NH}_{4}-\mathrm{N} \mathrm{m}^{-3} \mathrm{~h}^{-1}$, and at further increased rates up to $9.4 \mathrm{~g} \mathrm{NH}_{4}-\mathrm{N} \mathrm{m}^{-3} \mathrm{~h}^{-1}$, the $\mathrm{ARR}_{\max }$ remained constant. It should be noted that the loads were not applied with increasing order (i.e. the last load shift experiment had an ALR of $5.2 \mathrm{~g} \mathrm{NH}_{4}-\mathrm{N} \mathrm{m}^{-3} \mathrm{~h}^{-1}$ and an ARR of $3.3 \mathrm{~g} \mathrm{NH}_{4}-\mathrm{N} \mathrm{m}^{-3} \mathrm{~h}^{-1}$ ), yet the same ARR $\max$ for the column was observed for all loading rates.

Short term ammonium load upshift experiments, at double the reference hydraulic loading rate $\left(7.9 \mathrm{~m} \mathrm{~h}^{-1}\right)$, showed similar ARRs as those observed under similar ALRs at the reference hydraulic loading rate. Complete removal of ammonium was observed up to an ALR of $2.7 \mathrm{~g} \mathrm{NH}_{4}-\mathrm{N} \mathrm{m}^{-3} \mathrm{~h}^{-1}$, with no detectable concentrations of ammonium in the effluent up to an ALR of $3.5 \mathrm{~g} \mathrm{NH}_{4}-\mathrm{N} \mathrm{m}^{-3} \mathrm{~h}^{-1}$ (Fig. 4). Even with an ALR of up to $10.3 \mathrm{~g} \mathrm{NH}_{4}-\mathrm{N}$ $\mathrm{m}^{-3} \mathrm{~h}^{-1}$, the same $A R R_{\max }$ was observed as that under reference hydraulic loadings. 


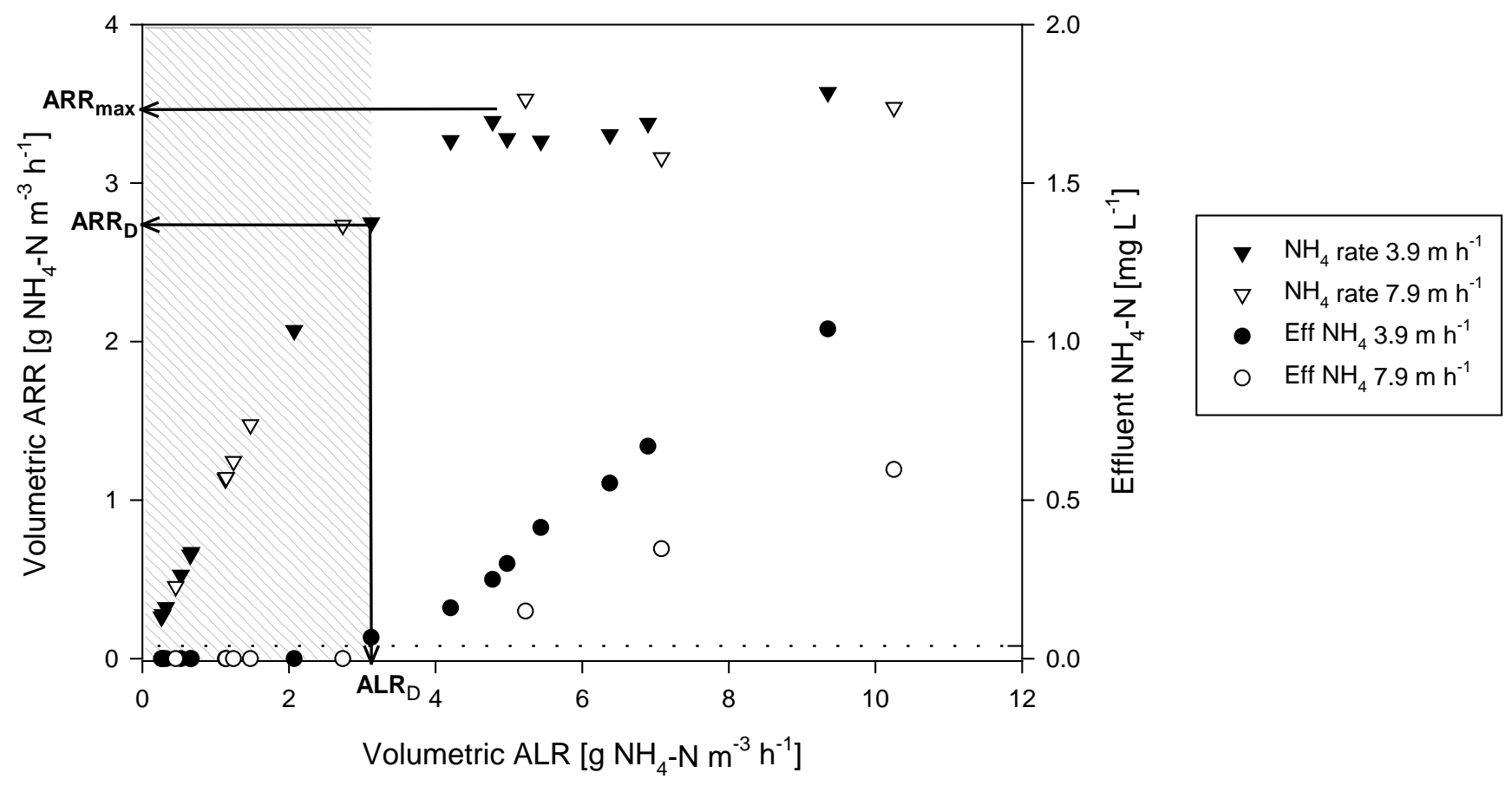

Figure 4: Volumetric ammonium removal rate (left axis) and effluent ammonium concentration (right axis) as a function of volumetric ammonium loading rate. The shaded areas show the safe operating window for removing ammonium and the dotted line shows the regulatory limit for ammonium $\left(0.04 \mathrm{mg} \mathrm{NH}_{4}-\mathrm{N} \mathrm{L}^{-1}\right)$. $A L R_{d}$ and $A R R_{d}$ show the maximum acceptable ammonium loading and removal rates for Danish drinking water guidelines.

The $A_{R R}$ max of $3.4 \mathrm{~g} \mathrm{NH}_{4}-\mathrm{N} \mathrm{m}^{-3} \mathrm{~h}^{-1}$ is in the range reported by others for trickling filters and granular activated carbon. De Vet et al. (2011) found the maximum volumetric nitrification rate between 1.5 and $6 \mathrm{~g} \mathrm{NH}_{4}-\mathrm{N} \mathrm{m}^{-3} \mathrm{~h}$ ${ }^{1}$ in drinking water trickling filters with influent ammonium concentrations from 1 to $6 \mathrm{mg} \mathrm{NH}_{4} \mathrm{~L}^{-1}$. Laurent et al. (2003) reported a potential nitrifying activity of between 2.53 and $4.35 \mathrm{~g} \mathrm{NH}_{4}-\mathrm{N} \mathrm{m}^{-3} \mathrm{~h}^{-1}$ in GAC filters with influent ammonium concentrations between 0.42 and $0.55 \mathrm{mg} \mathrm{NH}_{4}-\mathrm{N} \mathrm{L}^{-1}$. These volumetric activities are similar to the ammonium removal capacity in our filter, even though our inlet ammonium concentrations were significantly lower.

At both examined hydraulic loading rates, there is a rapid transition from first to zero order ammonium removal at ALRs close to the maximum ARR of the filter (Fig 4). This result is surprising because it was expected that increasing the hydraulic loading would increase the ARR (Stembal et al., 2005; van den Akker et al., 2008; Lopato et al., 2013) due to a decrease in the external mass transfer resistance (Rittmann and MacCarty, 2001). Indeed, while the external mass transfer layer decreased by $21 \%$, by increasing the hydraulic loading rate from 3.9 to $7.9 \mathrm{~m} \mathrm{~h}^{-1}$ (Supplementary material), this did not result in an increase in the ammonium removal rates. The $\mathrm{K}^{*}$ value, which compares the maximum utilization rate of the biofilm to the external mass transfer resistance (Rittmann and MacCarty, 2001), was between 2 and 4 in the column (Table 3A Supplementary material), at both hydraulic loading rates, indicating that ammonium removal was not limited by external mass 
transfer, but by reactions in the biofilm phase. The low ALR applied under normal reference operating conditions leads to biofilms that are thin and shallow with respect to the substrate $(f$ value of 0.40 , Supplementary material Table 4A), confirming that nitrification in the pilot column is limited by biokinetics. This finding is significant when determining safe operating windows in rapid sand filters, in terms of hydraulic and ALRs. In these filters, ammonium removal was only a function of total ALR, and not a function of the hydraulic loading rate or inlet ammonium concentration individually.

\subsection{Safe operating windows}

When treating drinking water it is important to know the safe operating windows, in terms of hydraulic loading rate and inlet ammonium concentration, where water quality guidelines for treated water are satisfied. In our column, ammonium removal was determined to only be a function of ALR. The safe operating window for this filter, in terms of ammonium removal, was determined by the ALR where ammonium in the effluent was found to be at the Danish regulatory guideline value. Because of strict regulatory guidelines for ammonium $(0.04 \mathrm{mg}$ $\mathrm{NH}_{4}-\mathrm{N} \mathrm{L}^{-1}$ ), the maximum allowable ALR on the filter should not exceed $3.1 \mathrm{~g} \mathrm{NH}_{4}-\mathrm{N} \mathrm{m}^{-3} \mathrm{~h}^{-1}$ (Fig. 4). Any loading rate below this was in the first order window of operation, which showed one-to-one removal. There was a small range of ALRs between 3.1 and $4.2 \mathrm{~g} \mathrm{NH}_{4}-\mathrm{N} \mathrm{m}^{-3} \mathrm{~h}^{-1}$ where ammonium removal changed from first to zero order. At the observed maximum allowable ALR, the ammonium removal capacity in the filter was more than 5 times higher than the average ALR, and almost 3 times higher than the maximum ALR found under reference operating conditions.

It was more difficult to meet nitrite guidelines than to meet the ammonium guidelines (Fig. 5). The NRR of the column was very similar to the ARR, but since the Danish guideline values for nitrite are an order of magnitude lower than those for ammonium $\left(0.003 \mathrm{mg} \mathrm{NO}_{2}-\mathrm{N} \mathrm{L}^{-1}\right)$, the safe operating window for nitrite removal was lower than for ammonium removal, $1.2 \mathrm{~g} \mathrm{NH}_{4}-\mathrm{N} \mathrm{m}^{-3} \mathrm{~h}^{-1}$. The desired nitrite effluent concentration determined the maximum allowable ALR in the filter. The maximum allowable ALR is subjective, and depends on the acceptable effluent concentrations. This would change dramatically if the $\mathrm{EU}$ drinking water directive values for ammonium and nitrite $\left(0.4 \mathrm{mg} \mathrm{NH}_{4}-\mathrm{N} \mathrm{L}^{-1}\right.$ and $\left.0.15 \mathrm{mg} \mathrm{NO}_{2}-\mathrm{N} \mathrm{L}^{-1}\right)$ were used instead of the Danish guideline values, with the maximum allowable ARL increasing to approximately $6 \mathrm{~g} \mathrm{NH}_{4}-\mathrm{N} \mathrm{m}^{-3} \mathrm{~h}^{-1}$. This is twice as large as the maximum allowable ALR required to meet Danish drinking water guidelines. For nitrite, the maximum allowable ALR would be higher than any of the ALRs examined in this study. The increase in nitrite in the effluent could be due to small amounts of ammonium being oxidized lower in the filter, and not enough active NOB at these depths to completely remove the nitrite. Despite the strict Danish regulatory guidelines, the filter was able to remove both ammonium and nitrite to guideline values at the maximum ALR observed under reference operating conditions. This extra nitrification capacity of the filter allows safe operation under the sudden large changes in both influent ammonium concentration and hydraulic loading rate. 


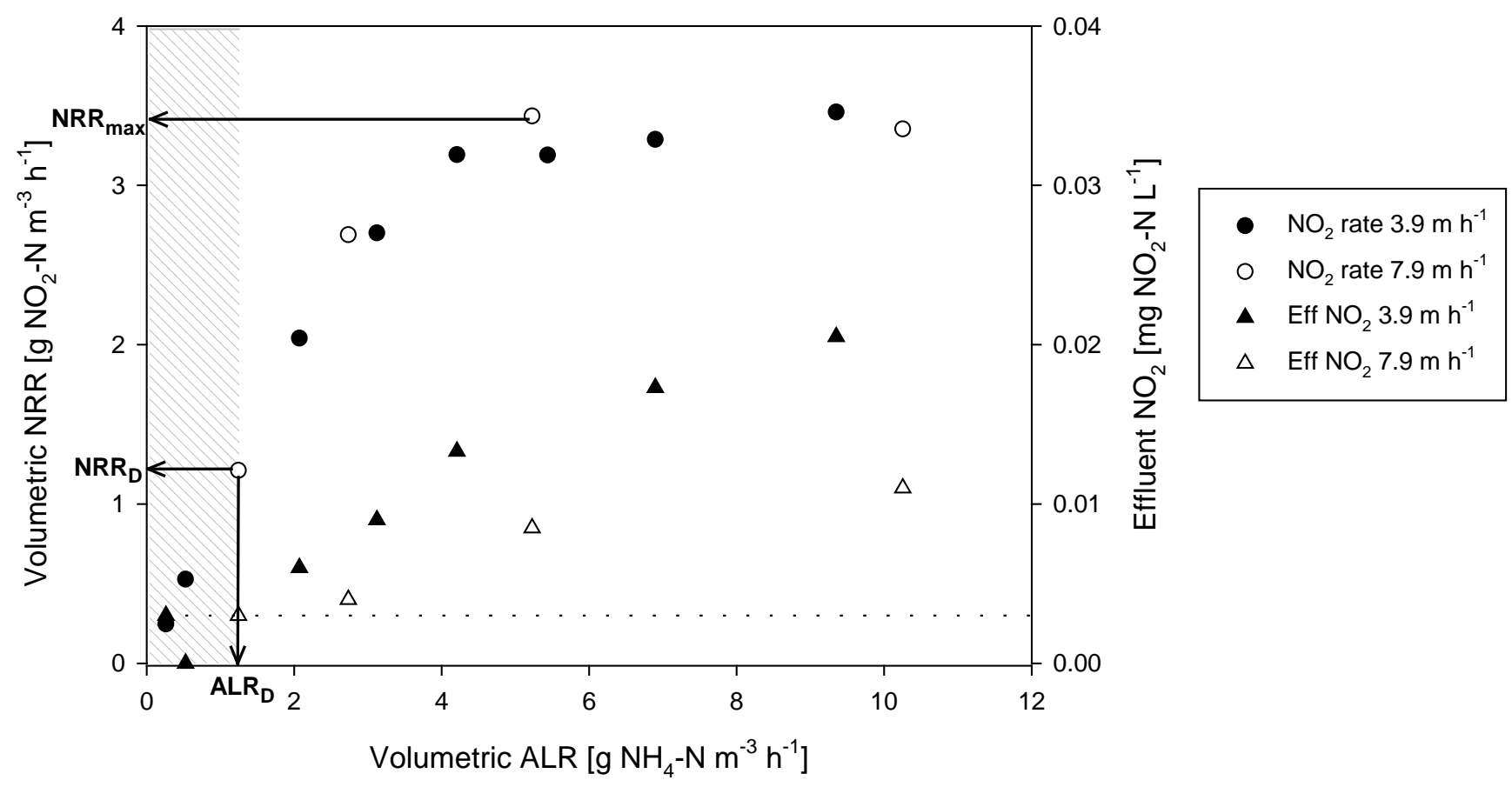

Figure 5: Volumetric nitrite removal rate (left axis) and effluent nitrite concentration (right axis) as a function of volumetric ammonium loading rate. The shaded area shows the safe operating window for nitrite removal and the dotted line shows the regulatory limit for nitrite $\left(0.003 \mathrm{mg} \mathrm{NO}_{2}-\mathrm{N} \mathrm{L}^{-1}\right)$. The $\mathrm{NRR}_{\mathrm{d}}$ shows the maximum NRR achieved to meet Danish drinking water guidelines.

\subsection{Ammonium removal with depth}

Depth profiles were taken to examine how ammonium removal varied with depth in the filter, and to investigate how removal changed with increased ammonium and hydraulic loading rates (Fig. 6). The profiles consistently showed stratified removal, with most of the ammonium removal occurring at the top of the filter. At the bottom of the filter, little ammonium removal was observed, even at the highest ALR.

Others have reported similar stratified nitrification in GAC filters (Andersson et al., 2001; Kihn et al., 2000), and nitrifying trickling filters (van den Akker et al., 2008). Tekerlekopoulou and Vayenas (2008) observed stratification of ammonium removal with depth under varying ammonium loads in nitrifying trickling filters, with most of the removal occurring at the top of the filter, and very little occurring deeper in the filter bed. Ammonium removal that is not stratified, but uniform throughout the depth of the filter, has been reported by Lopato et al. (2013), who examined ammonium removal in biological rapid sand filters, and by (Han et al., 2013) in biological aerated filters.

There could be several reasons why nitrification is stratified and decreases with depth in the Islevbro filter. Under normal reference loading conditions, the ammonium is removed to below detectable limits in the top 20 
$\mathrm{cm}$ of the filter. Only very low concentrations of ammonium would be available to microbes at lower depths, limiting the growth of nitrifying organisms lower in the filter. Another reason for decreased removal with depth could be nutrient limitations, such as phosphorus. Inlet phosphorus concentrations to the filter were relatively low at $0.01 \mathrm{mg} \mathrm{P} \mathrm{L}^{-1}$. The majority of any easily available nutrients, such as phosphorus, might be consumed at the top of the filter, limiting biomass growth lower in the column. Backwashing the filters did not remove the stratification in the filter. The buildup of precipitates over time leaves the top of the filter with larger, less dense filter material, which stay at the top of the filter after the backwash (Table 1A Supplementary Material).

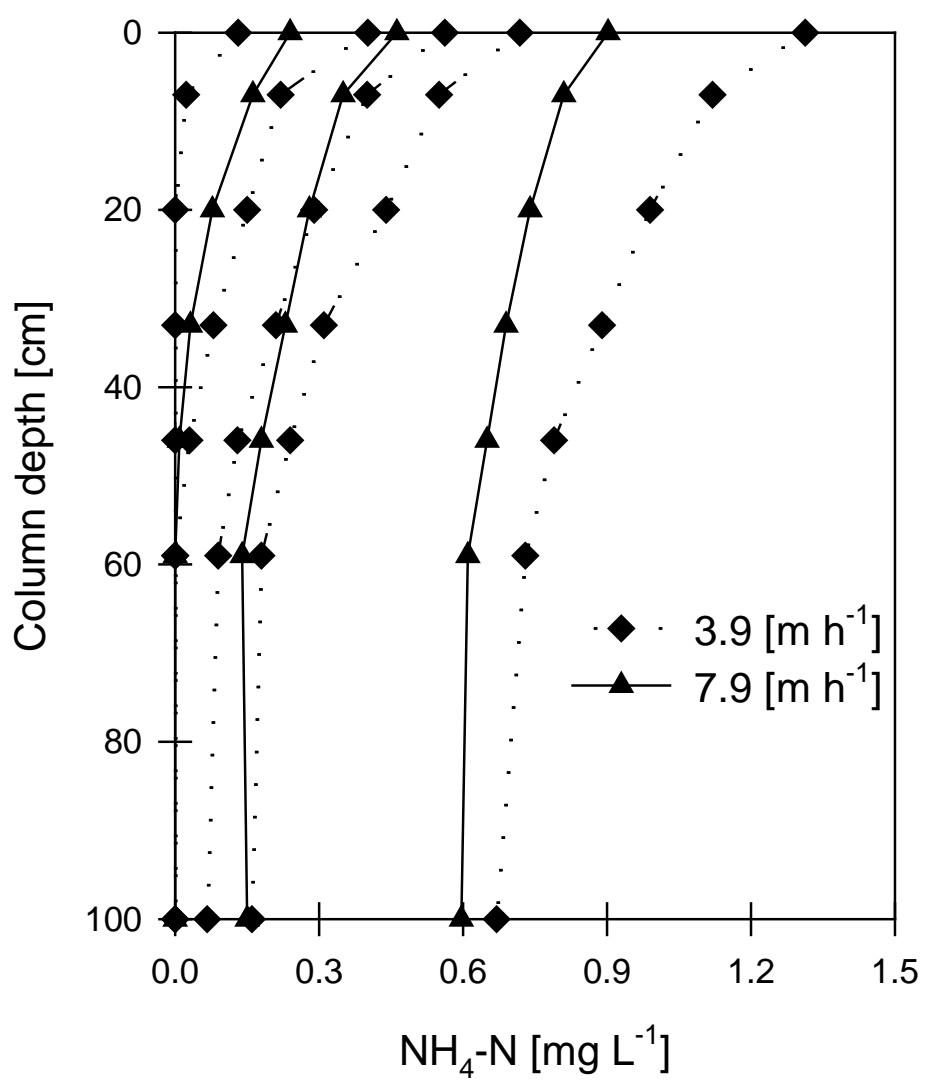

Figure 6: Ammonium depth profiles at hydraulic loading rates of 3.9 and $7.9 \mathrm{~m} \mathrm{~h}^{-1}$. The influent water is represented by a depth of 0 while the effluent is shown as a depth of $100 \mathrm{~cm}$.

The ammonium depth profiles were used to calculate the volumetric ARR at various depths in the pilot filter as a function of ALR (Fig. 1A Supplementary Material). The rates were determined from the data shown in Fig. 6, by calculating the per unit volume difference in ammonium load in the influent and effluent, and at depths of $7,20,33,46$, and $59 \mathrm{~cm}$. From this, the maximum volumetric ARR at each depth for both hydraulic loading rates was calculated (Fig. 7A). The reported depths are the middle points between measured depths. 
The maximum volumetric ARR are very similar for both hydraulic loading rates at every depth in the filter, showing that the hydraulic loading rate has little effect on ammonium removal. The largest ARR for both hydraulic loadings can be seen in the top of the filter, with 9.8 and $10.7 \mathrm{gNH}_{4}-\mathrm{N} \mathrm{m}^{-3} \mathrm{~h}^{-1}$ at hydraulic loading rates of 3.9 and $7.9 \mathrm{~m} \mathrm{~h}^{-1}$. The rate decreased sharply with depth, with the bottom layer of the filter having much lower removal than the top layer.

Extra ammonium removal capacity in the filter was determined by subtracting the volumetric ARR found under reference operating conditions, from the mean maximum ARR of both hydraulic loading rates. Most of the extra ammonium removal capacity in these filters was found at the top of the filter (Fig. 7A). At the normally low ammonium loading rates that these filters operate under, limited extra capacity was expected in the lower parts of the filter, due to the limited amount of ammonium that penetrates deeper into the filter. Despite the low ammonium loads in the lower depths of the filter, there was some additional removal capacity. In filters with higher ammonium loading rates, van den Akker et al. (2008) reported that the lower depths of a nitrifying trickling filter had extra nitrification capacity, which is beneficial in meeting water guidelines under rapidly changing ammonium loads.

\subsection{Density and distribution of $A O B$}

The total $A O B$ density in the filter immediately before, and after the first filter run of the experiments, differed by only $3 \%$ (Table 5A Supplementary Material), supporting the assumption that AOB densities were essentially constant for all load-shift experiments. AOB densities were stratified with depth (Fig. 7B), with 4 to 5 times higher density at the shallowest sampling depth $\left(7 \mathrm{~cm}, 1.2 \times 10^{8}\right.$ per gram dww sand), compared to lower sampling depths $\left(3.2 \times 10^{7}\right.$ per gram dww sand at $20 \mathrm{~cm}, 2.1 \times 10^{7}$ per gram dww sand at $\left.46 \mathrm{~cm}\right)$. The AOB fraction of total bacteria, decreased with depth. AOBs constituted $1.3 \%$ at the top and $0.4 \%$ at the bottom of the filter of all Eubacteria (Table 6A Supplementary Material).

Different distributions of nitrifying biomass have been observed in water filters used to remove ammonium from drinking water. De Vet et al. (2011) found that ammonium oxidizing prokaryotes (AOP) increased between two depths in a non-subsurface aerated filter, while they decreased between the same depths in a subsurface aerated filter. Using nitrifying activity potential as an indirect way to quantify nitrifying biomass, Laurent et al. (2003) found that in general the biomass was distributed uniformly throughout the depth of a full scale GAC filters, while Kinn et al. (2000) showed stratified nitrifying biomass in a full scale activated carbon filter. Here, we used qPCR to directly quantify the distribution of AOB throughout the depth of the filter, at a higher resolution, over depth, than previously reported. The higher resolution is needed because it shows the extent of the stratification in the filter with respect to both $A O B$ and nitrification, and thus directly relates $A O B$ to ammonium removal.

Recent attention has been paid to the role of AOA in ammonium oxidation, although their quantitative contribution to ammonium oxidation in drinking water filters has yet to be determined (Niu et al., 2013). Based on an amoA based quantification, $A O A$ and $A O B$ were found to be nearly equally abundant in the filter, with AOA comprising $25 \%$ to $53 \%$ of the ammonium oxidizers (Fig. $7 \mathrm{C}$ ). AOB were more dominant at the top of the filter. Despite this seemingly abundance of AOA, it is not clear to what extent they contribute to NH4 removal in these systems, as the reported cell specific rates of ammonium oxidation are an order of magnitude lower for AOA compared with AOB (Prosser and Nicol, 2012). 
AOA are thought to be more abundant in environments with low ammonium concentrations $\left(<0.2 \mathrm{mg} \mathrm{NH}_{4}-\mathrm{N} \mathrm{L}^{-}\right.$ ${ }^{1}$ ), due to their much higher affinity for ammonium (French et al., 2012). In trickling filters with high ammonium concentrations (1.5-4.7 $\mathrm{mg} \mathrm{NH}_{4}-\mathrm{N} \mathrm{L}^{-1}$ ), de Vet et al. (2011) reported minimal AOA contribution to ammonium oxidation. In GAC filters treating low levels of ammonium ( $0.1 \mathrm{mg} \mathrm{NH}_{4}-\mathrm{N} \mathrm{L}^{-1}$ ), Niu et al. (2013) concluded that $A O A$, and not $A O B$, were mainly responsible for ammonium oxidation. At an average inlet ammonium concentration of $0.1 \mathrm{mg} \mathrm{NH}_{4}-\mathrm{N} \mathrm{L}^{-1}$, it is debatable whether $\mathrm{AOB}$ or $\mathrm{AOA}$ support most of the ammonium oxidization. The very presence of $A O A$, however, suggests their physiological activity.
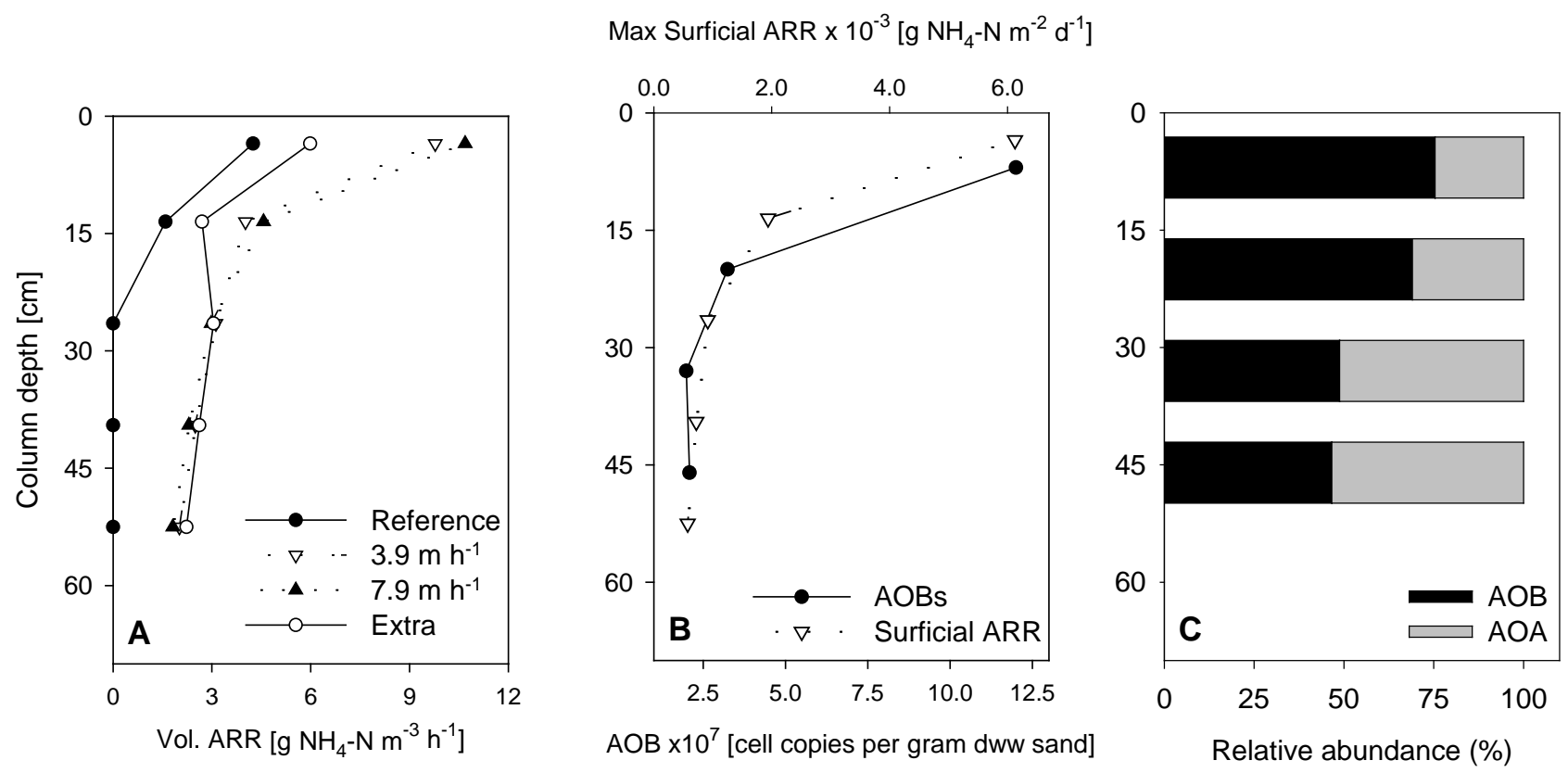

Figure 7: (A) Volumetric ARR between various depths in the pilot columns at reference operating conditions and the maximum ARR at hydraulic loading rates of 3.9 and $7.9 \mathrm{~m} \mathrm{~h}^{-1}$. The difference between the average maximum ARRs and the reference ARR is the extra ammonium removal capacity. Values at each depth for the maximum rates are based on the average of the highest 3 ALRs, except for the bottom 3 columns depths at the hydraulic loading rate of $7.9 \mathrm{~m} \mathrm{~h}^{-1}$ where only the highest two ALRs are used. (B) Number of AOB using $16 \mathrm{~S}$ rRNA [cell copy per gram dww sand] (bottom axis) and the maximum surficial ARR $\left[\mathrm{g} \mathrm{NH}_{4}-\mathrm{N} \mathrm{m}^{-2} \mathrm{~d}^{-1}\right.$ ] (top axis) as a function of depth in the pilot column. (C) Relative abundance of $A O B$ to AOA with depth in the column quantifying the amoA gene.

\subsection{Relating ammonium removal to nitrifying biomass}

The maximum surficial ARR is important because it accounts for the surface area available for microbial growth in a biological filter. At reference operating conditions, the surficial ALRs in the column varied from $7.8 \times 10^{-5}$ to $4.0 \times 10^{-4} \mathrm{~g} \mathrm{NH}_{4}-\mathrm{N} \mathrm{m}^{-2} \mathrm{~h}^{-1}$ with an average of $2.0 \times 10^{-4} \mathrm{~g} \mathrm{NH}_{4}-\mathrm{N} \mathrm{m}^{-2} \mathrm{~h}^{-1}$, which is an order of magnitude lower than typical wastewater loading rates. The maximum surficial ARR, achieved in the column during the ammonium 
upshift experiments, was $1.2 \times 10^{-3} \mathrm{~g} \mathrm{NH}_{4}-\mathrm{N} \mathrm{m}^{-2} \mathrm{~h}^{-1}$, which was 6 times larger than the average surficial loading rate applied under reference operating conditions.

Depth profiles of the maximum surficial ARR in the filter appear strongly correlated with the distribution of AOB at different depths (Fig. 7B). The maximum surficial ARR at the top of the column $\left(6.1 \times 10^{-3} \mathrm{~g} \mathrm{NH}_{4}-\mathrm{N} \mathrm{m}^{-2}\right.$ $\mathrm{h}^{-1}$ ) was three times higher than at the next depth, and more than an order of magnitude higher than at the bottom of the filter. Van den Akker et al. (2008) observed surficial ARR as high as $0.09 \mathrm{~g} \mathrm{NH}_{4}-\mathrm{N} \mathrm{m}^{-2} \mathrm{~h}^{-1}$ in the top $30 \mathrm{~cm}$ of a nitrifying trickling filter at inlet ammonium concentrations of greater than $4 \mathrm{mg} \mathrm{NH}_{4}-\mathrm{N} \mathrm{L}^{-1}$. The much higher surficial ARR is likely to be due to larger densities of AOB due to higher ALRs.

Maximum cell specific ARRs for $A O B$, range from 0.4 to $0.7 \times 10^{2} \mathrm{fg} \mathrm{NH}_{4}-\mathrm{N} \mathrm{h}^{-1}$ cell ${ }^{-1}$ throughout the depth of the column, with an average of $0.6 \pm 0.2 \times 10^{2} \mathrm{fg} \mathrm{NH}_{4}-\mathrm{N} \mathrm{h}^{-1}$ cell ${ }^{-1}$. These values are in the range of those reported for nitrifying trickling filters $\left(0.02\right.$ to $5 \times 10^{2} \mathrm{fg} \mathrm{NH}_{4}-\mathrm{N} \mathrm{h}^{-1}$ cell ${ }^{-1}$, (de Vet et al., 2011)), and in continuous and batch reactors (0.1 to $3.2 \times 10^{2} \mathrm{fg} \mathrm{NH}_{4}-\mathrm{N} \mathrm{h}^{-1}$ (Prosser I., 1989)). The specific rates change only slightly with depth in our filter, revealing that the ARR throughout the depth of the filter is due to differences in $A O B$ density, rather than large differences in specific ARRs.

\section{Conclusions}

The overall conclusions showed that the examined rapid sand filters were robust, and able to remove both ammonium and nitrite to very strict water quality guidelines, even under sudden increased shifts in ammonium and hydraulic loading rates. Specifically it was observed that:

- A pilot-scale rapid sand filter accurately mimicked the full-scale rapid sand filter behavior in both biological and iron (flock) removal. The pilot-scale filter was used to investigate the filter response to changes in influent ammonium concentrations and hydraulic loadings.

- Ammonium removal depended on the ALR, the product of ammonium concentration and hydraulic loading, rather than influent concentration or hydraulic loading individually, and the hydraulic loading rate had little to no effect on the ARR. This was supported by the calculated $\mathrm{K}^{*}$ value, which implied external mass transfer resistance was not controlling.

- The maximum volumetric ARR of the column was $3.4 \mathrm{~g} \mathrm{NH}_{4}-\mathrm{N} \mathrm{m}^{-3} \mathrm{~h}^{-1}, 5$ times larger than the ALR observed under reference loading conditions.

- There is a large window of safe operating conditions for ammonium removal in the studied filters. Both sudden changes in inlet ammonium concentrations and hydraulic loading rates can be tolerated while still maintaining effluent concentrations below strict regulatory guidelines. The operating window, to safely meet Danish regulatory guidelines for nitrite, was much smaller $\left(1.2 \mathrm{~g} \mathrm{NH}_{4}-\mathrm{N} \mathrm{m}^{-3} \mathrm{~h}^{-1}\right)$ than ammonium ( $3.1 \mathrm{~g} \mathrm{NH}_{4}-\mathrm{N} \mathrm{m}^{-3} \mathrm{~h}^{-1}$ ), and was controlling the maximum acceptable ALR. Even so, nitrite was removed to below regulatory limits at the maximum ALR observed in the full-scale filters.

- Much of the extra ammonium removal was located in the top few $\mathrm{cm}$, with additional, but limited, capacity at the lower depths. The maximum volumetric and surficial ARRs were $10.7 \mathrm{~g} \mathrm{NH}_{4}-\mathrm{N} \mathrm{m}^{-3} \mathrm{~h}^{-1}$ and $6.1 \times 10^{-3} \mathrm{~g} \mathrm{NH}_{4}-\mathrm{N} \mathrm{m}^{-2} \mathrm{~h}^{-1}$ at the top of the column, considerably higher than the rates at the lowest active depths of the filter. 
- $A O A$ and $A O B$ were similar in abundance, although $A O A$ contribution to ammonium oxidation in the filter could not be determined in this study.

- The AOB density profiles mirrored the maximum surficial ARR profiles, indicating that $A O B$ density set the observed ARR.

\section{Acknowledgments}

This work was supported by the Danish Council for Strategic Research via the DW Biofilters project and by the UrbanWaterTech Research School. The authors would like to thank HOFOR for allowing us access to Islevbro water works and Krüger for use of their pilot container. We also wish to thank Karolina Tatari and Robbe Deleu for their assistance in this project as well as George Amoako, Søren Lind, and Peter Borch Nielsen for their technical expertise.

\section{References}

Aa, L.T.J. Van Der, Kors, L.J., Wind, A.P.M., Hofman, J.A.M.H., Rietveld, L.C., 2002. Nitrification in rapid sand filter : phosphate limitation at low temperatures. Water Supply 2, 37-46.

Andersson, a, Laurent, P., Kihn, a, Prévost, M., Servais, P., 2001. Impact of temperature on nitrification in biological activated carbon (BAC) filters used for drinking water treatment. Water Res. 35, 2923-34.

Biesterfeld, S., Farmer, G., Russell, P., Figueroa, L., 2003. Effect of Alkalinity Type and Concentration on Nitrifying Biofilm Activity. Water Environ. Res. 75, 196-204.

Clesceri, L.S., Greenberg, A.E., Eaton, A.D., 1998. Standard methods for the examination of water and wastewater, 20th ed. APHA, Washington.

De Vet, W.W.J.M., Kleerebezem, R., van der Wielen, P.W.J.J., Rietveld, L.C., van Loosdrecht, M.C.M., 2011. Assessment of nitrification in groundwater filters for drinking water production by qPCR and activity measurement. Water Res. 45, 4008-18.

De Vet, W.W.J.M., van Loosdrecht, M.C.M., Rietveld, L.C., 2012. Phosphorus limitation in nitrifying groundwater filters. Water Res. 46, 1061-9.

Ferris, M.J., Muyzer, G., Ward, D.M., 1996. Denaturing gradient gel electrophoresis profiles of 16S rRNAdefined populations inhabiting a hot spring microbial mat community. Appl. Environ. Microbiol. 62, 340-346.

Francis, C.A., Roberts, K.J., Beman, J.M., Santoro, A.E., Oakley, B.B., 2005. Ubiquity and diversity of ammoniaoxidizing archaea in water columns and sediments of the ocean. Proc. Natl. Acad. Sci. U. S. A. 102, 14683-8.

French, E., Kozlowski, J.A., Mukherjee, M., Bullerjahn, G., Bollmann, A., 2012. Ecophysiological characterization of ammonia-oxidizing archaea and bacteria from freshwater. Appl. Environ. Microbiol. 78, 5773-80. 
Han, M., Zhao, Z., Gao, W., Cui, F., 2013. Study on the factors affecting simultaneous removal of ammonia and manganese by pilot-scale biological aerated filter (BAF) for drinking water pre-treatment. Bioresour. Technol. $145,17-24$.

Hermansson, A., Lindgren, P.E., 2001. Quanitification of ammonia-oxidizing bacteria in arable soil by real-time PCR. Appl. Environ. Microbiol. 67, 972-976.

Kihn, a, Laurent, P., Servais, P., 2000. Measurement of potential activity of fixed nitrifying bacteria in biological filters used in drinking water production. J. Ind. Microbiol. Biotechnol. 24, 161-166.

Kihn, A, Andersson, Laurent, P, Servais, Prevost, M, 2002. Impact of filtration material on nitrification in biological filters used in drinking water production. IWA, London, ROYAUME-UNI.

Kors, L.J., Moorman, J.H.N., Wind, A.P.M., van der Hoek, J.P., 1998. Nitrification and low temperature in a raw water reservoir and rapid sand filters. Water Sci. Technol. 37, 169-176.

Lane, D.J., 1991. 16S/23S rRNA sequencing. Nucleic Acid Tech. Bact. Syst. 125-175.

Laurent, P., Kihn, A., Andersson, A., Servais, P., 2003. Impact of backwashing on nitrification in the biological activated carbon filters used in drinking water treatment. Environ. Technol. 24, 277-287.

Lee, C., Kim, J., Shin, S.G., Hwang, S., 2006. Absolute and relative QPCR quantification of plasmid copy number in Escherichia coli. J. Biotechnol. 123, 273-280.

Lee, C.O., Albrechtsen, H.-J., Smets, B.F., Boe-Hansen, R., Lind, S., Binning, P., November 3-7, 2013. Phosphate limitation in biological rapid sand filters used to remove ammonium from drinking water. American Water Works Association, Water Quality and Technology Conference. Long Beach, CA, USA.

Lopato, L., Galaj, Z., Delpont, S., Binning, P.J., Arvin, E., 2011. Heterogeneity of Rapid Sand Filters and Its Effect on Contaminant Transport and Nitrification Performance. J. Environ. Eng. 137, 248-257.

Lopato, L., Röttgers, N., Binning, P.J., Arvin, E., 2013. Heterogeneous Nitrification in a Full-Scale Rapid Sand Filter Treating Groundwater. J. Environ. Eng. 139, 375-384.

Lytle, D. a., White, C., Williams, D., Koch, L., Nauman, E., 2013. Innovative Biological Water Treatment for the Removal of Elevated Ammonia. J. Am. Water Works Assoc. E524-E539.

Metcalf, L., Eddy, H.P., Tchobanoglous, G., 2004. Wastewater engineering : treatment, disposal, and reuse, McGraw-Hill series in water resources and environmental engineering. McGraw-Hill, New York.

Miljøministeriet, 2014. Statutory order on water quality and surveillance of water supply facilities, BEK nr 292 (Bekendtgørelse om vandkvalitet og tilsyn med vandforsyningsanlæg, in Danish) Danish Ministry of Environment.

Niu, J., Kasuga, I., Kurisu, F., Furumai, H., Shigeeda, T., 2013. Evaluation of autotrophic growth of ammoniaoxidizers associated with granular activated carbon used for drinking water purification by DNA-stable isotope probing. Water Res. 47, 7053-65.

Prosser I., J., 1989. Autotrophic nitrification in bacteria. Adv. in Microbial Physiology, Vol 30, APL 30, 125-181. 
Prosser, J.I., Nicol, G.W., 2012. Archaeal and bacterial ammonia-oxidisers in soil: the quest for niche specialisation and differentiation. Trends Microbiol. 20, 523-31.

Ririe, K.M., Rasmussen, R.P., Wittwer, C.T., 1997. Product Differentiation by Analysis of DNA Melting Curves during the Polymerase Chain Reaction. Anal. Biochem. 245, 154-160.

Rittmann, B.E., MacCarty, P.L., 2001. Environmental Biotechnology: Principles and Applications. McGraw-Hill series in water resources and environmental engineering. McGraw-Hill, Boston.

Rittmann, B.E., Tang, Y., Meyer, K., Bellamy, W.D., 2012. Biological Processes. Chpt. 17 in Water Treatment Plant Design. American Water Works Association.

Rotthauwe, J., Witzel, K., Liesack, W., 1997. The ammonia monooxygenase structural gene amoA as a functional marker: molecular fine-scale analysis of natural ammonia-oxidizing populations. Appl. Envir. Microbiol. 63, 4704-4712.

Sahabi, D.M., Takeda, M., Suzuki, I., Koizumi, J., 2009. Removal of Mn2+ from water by “aged" biofilter media: The role of catalytic oxides layers. J. Biosci. Bioeng. 107, 151-157.

Stembal, T., Markic, M., Ribicic, N., Briski, F., Sipos, L., 2005. Removal of ammonia, iron and manganese from groundwaters of northern Croatia--pilot plant studies. Process Biochem. 40, 327-335.

Stumm, W., Lee, G.F., 1961. Oxygenation of Ferrous Iron. Ind. Eng. Chem. 53, 143-146.

Tatari, K., Smets, B.F., Albrechtsen, H.-J., 2013. A novel bench-scale column assay to investigate site-specific nitrification biokinetics in biological rapid sandfilters. Water Res. 47, 6380-6387.

Tekerlekopoulou, A.G., Vayenas, D. V, 2008. Simultaneous biological removal of ammonia, iron and manganese from potable water using a trickling filter. Biochem. Eng. J. 39, 215-220.

USEPA, 2007. Inductively Coupled Plasma-Atomic Emission Spectometry, EPA 6010C. USEPA Off. Res. Dev. Washingt.

Van den Akker, B., Holmes, M., Cromar, N., Fallowfield, H., 2008. Application of high rate nitrifying trickling filters for potable water treatment. Water Res. 42, 4514-24.

Wilczak, A, Jacangelo, J, G., Marcinko, J, P., Odell, L, H., Kirmeyer, G, J., Wolfe, R, L., 1996. Occurrence of nitrification in chloraminated distribution systems. American Water Works Association, Denver, CO, ETATSUNIS. 


\section{Effects of dynamic operating conditions on nitrification in biological rapid sand filters for drinking water treatment}

Carson O. Lee ${ }^{*}$, Rasmus Boe-Hansen ${ }^{\text {, }}$, Sanin Musovic, Barth Smets, Hans-Jørgen Albrechtsen, Philip Binning

Department of Environmental Engineering, Technical University of Denmark, Miljøevej 113, 2800 Kgs. Lyngby, Denmark

${ }^{a}$ Krüger A/S, Gladsaxevej 363, 2860 Søborg, Denmark

The volumetric ammonium removal rates as a function of ammonium loading rate at the different depths in the pilot filter is shown in Figure 1A. The considered ALR is for the entire column and not the individual depths, and is defined in the main text of the manuscript.
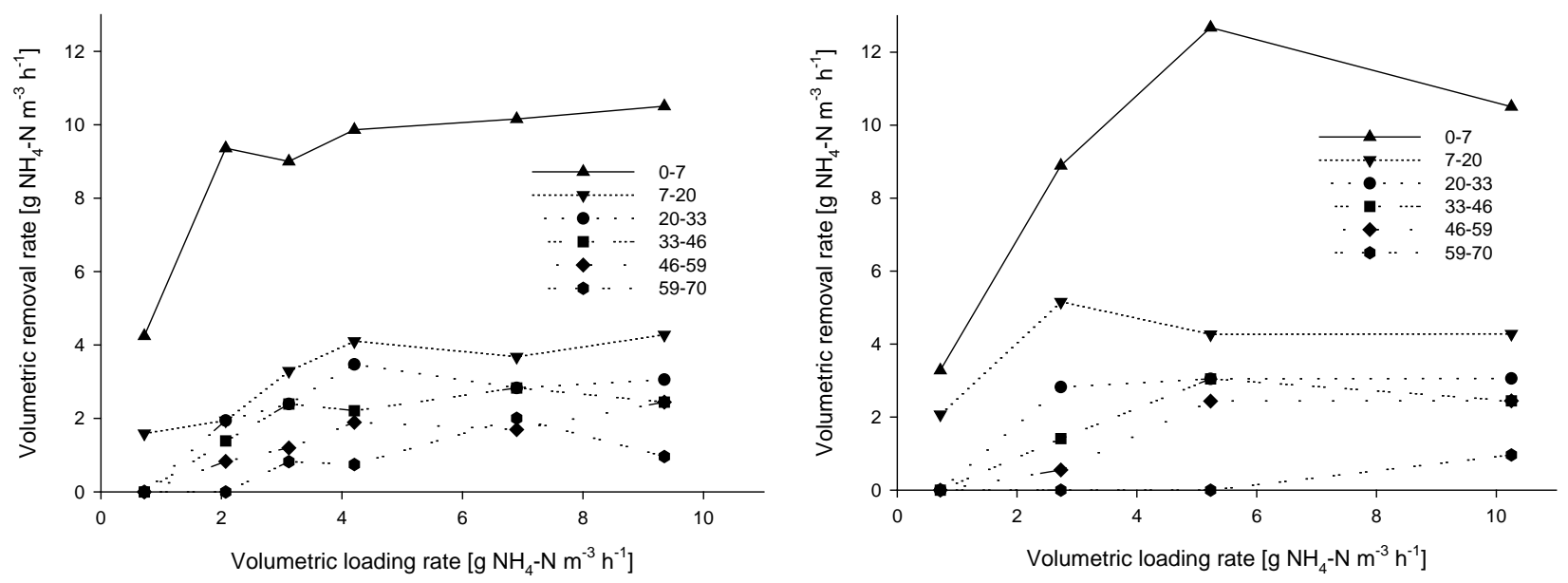

Figure 1A: Volumetric $\mathrm{NH}_{4}-\mathrm{N}$ removal rate of ammonium $\left[\mathrm{g} \mathrm{NH}_{4}-\mathrm{N} \mathrm{m}^{-3} \mathrm{~h}^{-1}\right.$ ] as a function of volumetric $\mathrm{NH}_{4}-\mathrm{N}$ loading rate $\left[\mathrm{g} \mathrm{NH}_{4}-\mathrm{N} \mathrm{m}^{-3} \mathrm{~h}^{-1}\right.$ ] at different depths in the filter for hydraulic loading rates of $3.9 \mathrm{~m} \mathrm{~h}^{-1}$ (left) and $7.8 \mathrm{~m} \mathrm{~h}^{-1}$ (right).

Table 1A: Operating and design parameters for the pilot column and full-scale filter at Islevbro water works. Adapted from Lee et al. (2013).

\begin{tabular}{lll}
\hline Parameter & Full scale & Pilot columns \\
\hline Filter area & $18 \mathrm{~m}^{2}$ & $.071 \mathrm{~m}^{2}$ \\
Filter Volume & $12.6 \mathrm{~m}^{3}$ & $\sim 0.05 \mathrm{~m}^{3}$ \\
Hydraulic loading rate & $4 \mathrm{~m} / \mathrm{h}$ & $3.9 \mathrm{~m} / \mathrm{h}$ \\
Filter run time & $10-23$ days & $10-23$ days \\
\hline
\end{tabular}


Media properties for the filter material are shown in Table 2A. Sieve analyses were used to determine the average grain size of the media at different depths. The analysis was further used to estimate the surface area of the filter media by taking a weighted average of the sand radius and the assumption that the sand grains were round. The surface area at the difference depths $\left(\mathrm{S}_{\text {col }}\right)$ was determined using $S=S_{w}{ }^{*} N^{*} \rho$, where $S_{w}$ is the weighted average surface area per sand grain as determined from the sieved analysis, $\mathrm{N}$ is the number of sand grains per gram of filter material, and $\rho$ is the DWW density of the sand. The larger surface area available at the bottom of the filter is due to both the increased density of the sand at the bottom of the filter and that $\mathrm{N}$ was approximately the same in the bottom and middle of the filter despite the slightly larger average diameter of sand at the bottom of the filter.

Table 2A: Media properties of the Islevbro filter sand at depths of 0-10 (top), 10-20 (middle), and 35-50 cm (bottom).

\begin{tabular}{lllll}
\hline Media property & Units & Top & Middle & Bottom \\
\hline Average grain size & $\mathrm{mm}$ & 1.4 & 0.8 & 1 \\
Surface area (S) & $\mathrm{m}^{2}$ surface area $\mathrm{m}^{-3}$ & 1670 & 2210 & 3330 \\
& & & & \\
Density & $\mathrm{kg} \mathrm{drained}$ wet sand $\mathrm{m}^{-3}$ & 1100 & 1600 & 1700 \\
$\mathbf{d}_{\mathbf{1 0}}$ & $\mathrm{mm}$ & 1.1 & 0.5 & 0.6 \\
$\mathbf{d}_{\mathbf{6 0}}$ & $\mathrm{mm}$ & 1.6 & 0.9 & 1.2 \\
$\mathbf{d}_{\mathbf{6 0}} / \mathbf{d}_{\mathbf{1 0}}$ & & 1.5 & 1.8 & 2.0 \\
$\mathbf{S}_{\mathbf{w}}$ & $\mathrm{mm}^{2}$ & 7.7 & 3.6 & 5.1 \\
$\mathbf{N}$ & Number of grains per gram & 198 & 385 & 382 \\
& of sand & & & \\
\hline
\end{tabular}

Holding all value constant except the hydraulic loading rates, the external mass transfer resistance can be determined by finding the thickness of the diffusion layer (L) (Rittmann and MacCarty, 2001). By increasing the hydraulic loading rate from 3.9 to $7.9 \mathrm{~m} \mathrm{~h}^{-1}$, there is a $21 \%$ decrease in the thickness of the diffusion layer as seen in Table 3A. To determine how much control the external mass transfer has on the flux of ammonium into the biofilm, the $\mathrm{K}^{*}$ value is used (Rittmann and MacCarty, 2001), as shown in Table 3A. Values of less than 1 indicate that external mass transport has a significant influence on the flux. Parameters for AOB were taken from Queinnec et al.(2006) and determination of the diffusion coefficient from ammonium followed Wilke and Chang (1955).

Table 3A: Parameters and equations used to determine $K^{*}$ at the top of the pilot column

\begin{tabular}{|c|c|c|c|}
\hline For calculations at $10^{\circ} \mathrm{C}$ & Units & $3.9 \mathrm{~m} / \mathrm{h}$ & $7.9 \mathrm{~m} / \mathrm{h}$ \\
\hline $\mathrm{L}=\mathrm{RL} * \mathrm{D}$ & $\mathrm{m}$ & 5.1E-05 & 4.1E-05 \\
\hline${ }^{\mathrm{a}} \mathbf{D}$ & $\mathrm{m}^{2} / \mathrm{s}$ & $1.5 \mathrm{E}-09$ & $1.5 \mathrm{E}-09$ \\
\hline$R L=d p /(S h * D)$ & & $3.4 \mathrm{E}+04$ & $2.7 \mathrm{E}+04$ \\
\hline$S h=1.09 / E^{*} \operatorname{Re}^{1 / 3} * S c^{1 / 3}$ & & 27.3 & 34.5 \\
\hline $\operatorname{Re}=d p * v / u$ & & 1.2 & 2.4 \\
\hline
\end{tabular}




\begin{tabular}{|c|c|c|c|}
\hline $\mathrm{Sc}=\mathrm{u} / \mathrm{D}$ & & 863.9 & 863.9 \\
\hline u & $\mathrm{m}^{2} / \mathrm{s}$ & $1.3 \mathrm{E}-06$ & $1.3 \mathrm{E}-06$ \\
\hline $\mathbf{E}$ & & 0.4 & 0.4 \\
\hline $\mathbf{v}$ & $\mathrm{m} / \mathrm{s}$ & $1.1 \mathrm{E}-03$ & $2.2 \mathrm{E}-03$ \\
\hline$d p$ & $\mathrm{~m}$ & $1.4 \mathrm{E}-03$ & $1.4 \mathrm{E}-03$ \\
\hline Df & $\mathrm{m}^{2} / \mathrm{s}$ & $1.2 \mathrm{E}-09$ & $1.2 \mathrm{E}-09$ \\
\hline$x f$ & $\mathrm{~kg} \mathrm{COD} / \mathrm{m}^{3}$ & 1.5 & 1.5 \\
\hline${ }^{b}$ umax at $10 \mathrm{C}$ & $1 / s$ & 3.0E-06 & 3.0E-06 \\
\hline${ }^{b_{K}}$ & $\mathrm{~kg} \mathrm{~N} / \mathrm{m}^{3}$ & 4.0E-04 & 4.0E-04 \\
\hline${ }^{b} Y$ & $\mathrm{Kg} \mathrm{COD/Kg} \mathrm{N}$ & 0.142 & 0.142 \\
\hline$q$ & $\mathrm{Kg} \mathrm{N} / \mathrm{Kg} \mathrm{COD} / \mathrm{s}$ & 2.1E-05 & 2.1E-05 \\
\hline$D / L$ & $\mathrm{~m} / \mathrm{s}$ & $2.9 \mathrm{E}-05$ & 3.7E-05 \\
\hline$\left(K /\left(q^{*} X f^{*} D f\right)\right)^{0.5}$ & $\mathrm{~s} / \mathrm{m}$ & $1.0 \mathrm{E}+05$ & $1.0 \mathrm{E}+05$ \\
\hline $\mathrm{K}^{*}$ & & 2.9 & 3.7 \\
\hline
\end{tabular}

a Calculated from (Wilke and Chang, 1955)

b Queinnec et al. (2006)

The $f$ parameter, used to determine if a biofilm is deep or shallow, was determined according to Rittmann and MacCarty (2001), see Table 4A. Values of less than 1 indicate that the biofilm is shallow.

Table 4A: Parameters and equations used to calculate the $f$ parameter.

\begin{tabular}{lrr}
\hline $\mathbf{f}=\tanh \left(\boldsymbol{\alpha}\left(\mathbf{S}^{*} / \mathbf{S}^{*} \min \right)^{\wedge} \boldsymbol{\beta}\right)$ & $\mathbf{0 . 4 0}$ \\
\hline $\mathbf{S}^{*}=\mathbf{S} / \mathbf{K}$ & 0.25 \\
$\mathbf{S}^{*} \min =\mathbf{b}^{\prime} /\left(\mathbf{Y}^{*} \mathbf{q}-\mathbf{b}^{\prime}\right)$ & 0.24 \\
${ }^{\mathrm{a}} \mathbf{b}^{\prime}$ & $1 / \mathrm{s}$ & $5.8 \mathrm{E}-07$ \\
$\boldsymbol{\alpha}$ & & $1.8 \mathrm{E}+00$ \\
$\boldsymbol{\beta}$ & & $5.2 \mathrm{E}-01$ \\
$\mathbf{S}$ & $\mathrm{Kg} \mathrm{N} / \mathrm{m3}$ & $1.0 \mathrm{E}-04$ \\
\hline $\mathbf{a} \quad$ Queinnec et al. (2006)
\end{tabular}

The reported $A O B$ densities in Fig. 7B are the average of the data for the two sampling days shown in Table 5A. The total $A O B$ per depth is found by multiplying the $A O B$ (cell copy number per gram drained wet weight) by the density of the filter material (Table 2A) and the volume of sand (cross sectional area of filter times the depth) and is shown in Table 5A

Table 5A: Number of $A O B$ with depth and the total $A O B$ calculated per section of the pilot column at the start of the experiments (sampling 1)and after one filter run during the load shift experiments (sampling 2). 


\begin{tabular}{lrrrrrrrr}
\hline \multicolumn{2}{l}{ AOB (Cell copy number) } & & & \multicolumn{5}{l}{ Total AOB per depth } \\
\hline $\begin{array}{l}\text { Depth } \\
\text { (cm) }\end{array}$ & 1st sampling & Std dev & 2nd sampling & Std dev & \multicolumn{2}{l}{$\begin{array}{l}\text { Depths } \\
\text { (cm) }\end{array}$} & \multicolumn{1}{l}{$\begin{array}{l}\text { 1st } \\
\text { sampling }\end{array}$} & \multicolumn{2}{l}{$\begin{array}{l}\text { 2nd } \\
\text { sampling }\end{array}$} \\
& $\mathbf{7}$ & $1.1 \mathrm{E}+08$ & $3.4 \mathrm{E}+06$ & $1.3 \mathrm{E}+08$ & $1.1 \mathrm{E}+06$ & $0-13$ & $1.1 \mathrm{E}+12$ & $1.3 \mathrm{E}+12$ \\
& 20 & $3.8 \mathrm{E}+07$ & $4.1 \mathrm{E}+05$ & $2.7 \mathrm{E}+07$ & $6.2 \mathrm{E}+05$ & $13-26$ & $5.5 \mathrm{E}+11$ & $4.0 \mathrm{E}+11$ \\
& 33 & $1.9 \mathrm{E}+07$ & $7.7 \mathrm{E}+05$ & $2.0 \mathrm{E}+07$ & $1.0 \mathrm{E}+06$ & $26-39$ & $2.8 \mathrm{E}+11$ & $3.0 \mathrm{E}+11$ \\
& 46 & $2.0 \mathrm{E}+07$ & $1.3 \mathrm{E}+06$ & $2.1 \mathrm{E}+07$ & $3.7 \mathrm{E}+06$ & $39-52$ & $3.2 \mathrm{E}+11$ & $3.3 \mathrm{E}+11$ \\
& & & & & & Sum & $2.27 \mathrm{E}+12$ & $2.34 \mathrm{E}+12$ \\
\hline
\end{tabular}

The total bacteria concentration as a function of depth for the two sampling days is shown in Table 6A. The average $A O B$ and total bacteria values are used to determine the ratio of $A O B$ to total bacteria throughout the depth of the filter.

Table 6A: Number of total bacteria with depth at the start of the experiments (sampling 1) and after one filter run during the load shift experiments (sampling 2).

\begin{tabular}{rrrrrr}
\hline \multicolumn{5}{l}{ Total Bacteria (Cell copy number) } \\
\hline Depth (cm) & 1st sampling & \multicolumn{1}{l}{ Std dev } & 2nd sampling & \multicolumn{1}{l}{ Std dev } \\
& 7 & $9.1 \mathrm{E}+09$ & $5.5 \mathrm{E}+08$ & $9.3 \mathrm{E}+09$ & $8.8 \mathrm{E}+08$ \\
20 & $4.9 \mathrm{E}+09$ & $7.4 \mathrm{E}+07$ & $6.9 \mathrm{E}+09$ & $2.5 \mathrm{E}+07$ \\
33 & $4.1 \mathrm{E}+09$ & $1.8 \mathrm{E}+08$ & $3.8 \mathrm{E}+09$ & $2.4 \mathrm{E}+09$ \\
46 & $4.2 \mathrm{E}+09$ & $2.4 \mathrm{E}+06$ & $7.0 \mathrm{E}+09$ & $3.9 \mathrm{E}+08$ \\
\hline
\end{tabular}

Table 7A: Raw and treated water parameters for Islevbro water works. Values are for $\mathbf{2 0 0 9}$ from a Københavns Energy report available at http://ke.dk/portal/pls/portal/docs/812003.PDF

\begin{tabular}{lcrr}
\hline Parameter & Units & $\begin{array}{r}\text { Raw } \\
\text { water }\end{array}$ & $\begin{array}{r}\text { Treated } \\
\text { water }\end{array}$ \\
\hline Temperature & ${ }^{\circ} \mathrm{C}$ & 9.5 & 9.6 \\
pH & & 7.1 & 7.5 \\
NVOC & $\mathrm{mg} / \mathrm{L}$ & 2.4 & 2.1 \\
Total Fe & $\mathrm{mg} / \mathrm{L}$ & 2.2 & 0.015 \\
Total Mn & $\mathrm{mg} / \mathrm{L}$ & 0.1 & $<0.005$ \\
Ammonium & $\mathrm{mg} / \mathrm{L}$ & 0.4 & 0.007 \\
Phosphorus & $\mathrm{mg} / \mathrm{L}$ & 0.02 & $<0.005$ \\
Chloride & $\mathrm{mg} / \mathrm{L}$ & 68 & 68 \\
Dissolved oxygen & $\mathrm{mg} / \mathrm{L}$ & 0.7 & 8.9 \\
Nickel & $\mu \mathrm{g} / \mathrm{L}$ & 3 & 3 \\
\hline
\end{tabular}




\section{References}

Lee, C.O., Albrechtsen, H.-J., Smets, B.F., Boe-Hansen, R., Lind, S., Binning, P., November 3-7, 2013. Phosphate limitation in biological rapid sand filters used to remove ammonium from drinking water, in: American Water Works Association, Water Quality and Technology Conference. Long Beach, CA, USA.

Queinnec, I., Ochoa, J.C., Wouwer, A. Vande, Paul, E., 2006. Development and calibration of a nitrification PDE model based on experimental data issued from biofilter treating drinking water. Biotechnol. Bioeng. 94, 209-222.

Rittmann, B.E., MacCarty, P.L., 2001. Environmental biotechnology: principles and applications, McGraw-Hill series in water resources and environmental engineering. McGraw-Hill, Boston.

Wilke, C.R., Chang, P., 1955. Correlation of diffusion coefficients in dilute solutions. AIChE J. 1, 264-270. 